\title{
ॠUSGS
}

Prepared in cooperation with the Bureau of Land Management, White River Field Office

Groundwater Chemistry and Water-Level Elevations in Bedrock Aquifers of the Piceance and Yellow Creek Watersheds, Rio Blanco County, Colorado, 2013-16

Scientific lavestigations Report $2018-5142$

U.S. Department of the Interior U.S. Geological Survey 
Cover: Yellow Creek, Rio Blanco County, Colorado. Photograph by Judith Thomas, U.S. Geological Survey. Back cover: Monitoring well, Rio Blanco County, Colo. Photograph by Judith Thomas, U.S. Geological Survey. 


\section{Groundwater Chemistry and Water-Level Elevations in Bedrock Aquifers of the Piceance and Yellow Creek Watersheds, Rio Blanco County, Colorado, 2013-16}

By Judith C. Thomas and Peter B. McMahon

Prepared in cooperation with the

Bureau of Land Management, White River Field Office

Scientific Investigations Report 2018-5142 


\title{
U.S. Department of the Interior \\ RYAN K. ZINKE, Secretary
}

\author{
U.S. Geological Survey \\ James F. Reilly II, Director
}

U.S. Geological Survey, Reston, Virginia: 2018

For more information on the USGS - the Federal source for science about the Earth, its natural and living resources, natural hazards, and the environment-visit https://www.usgs.gov or call 1-888-ASK-USGS.

For an overview of USGS information products, including maps, imagery, and publications,

visit https://store.usgs.gov.

Any use of trade, firm, or product names is for descriptive purposes only and does not imply endorsement by the U.S. Government.

Although this information product, for the most part, is in the public domain, it also may contain copyrighted materials as noted in the text. Permission to reproduce copyrighted items must be secured from the copyright owner.

Suggested citation:

Thomas, J.C., and McMahon, P.B., 2018, Groundwater chemistry and water-level elevations in bedrock aquifers of the Piceance and Yellow Creek watersheds, Rio Blanco County, Colorado, 2013-16: U.S. Geological Survey Scientific Investigations Report 2018-5142, 26 p., https://doi.org/10.3133/sir20185142.

ISSN 2328-0328 (online) 


\section{Contents}

Abstract

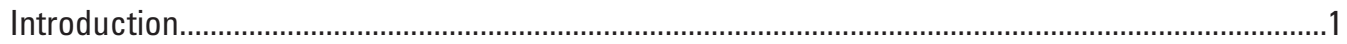

Purpose and Scope …….......................................................................................................

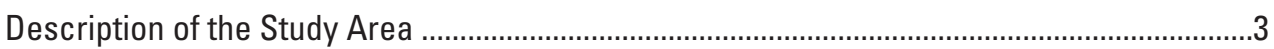

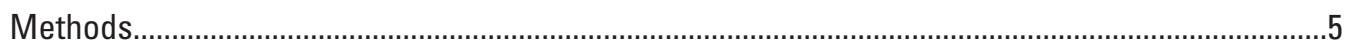

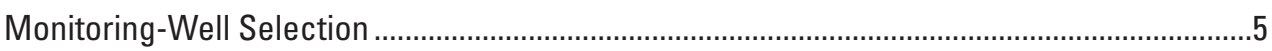

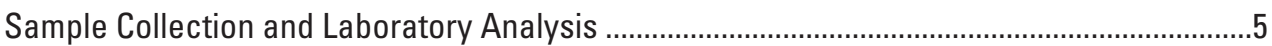

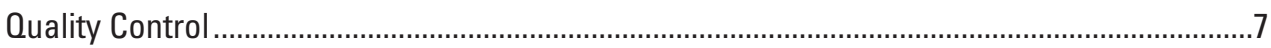

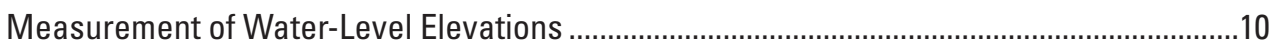

Groundwater Chemistry and Water-Level Elevations in Bedrock Aquifers.....................................10

Reduction-0xidation Processes...........................................................................................

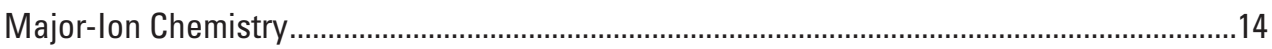

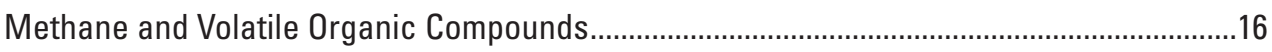

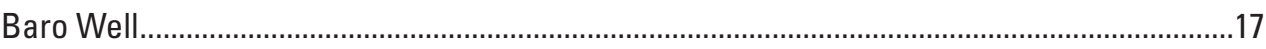

Water-Level Elevations ..................................................................................................19

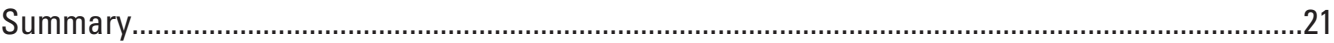

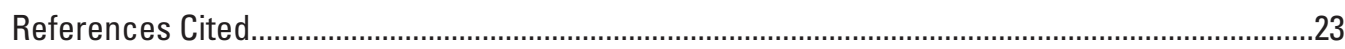

\section{Figures}

1. Map showing location of the Piceance Creek and Yellow Creek watersheds in the Piceance structural basin and the location of the monitoring-well network, Rio Blanco County, Colorado

2. Graph showing generalized stratigraphic column for the Piceance and Yellow Creek watersheds within the Piceance structural basin, Rio Blanco County, Colorado.

3. Graph showing methane concentrations in relation to sulfate concentrations for water samples collected from monitoring wells, 2013-16, Piceance and Yellow Creek watersheds, Rio Blanco County, Colorado.

4. Trilinear diagram showing water composition, in percent of constituents, collected from monitoring wells, 2013-16, Piceance and Yellow Creek watersheds, Rio Blanco County, Colorado

5. Graph showing time series plot of alkalinity and sulfate concentration data collected during phase 1 and phase 2 with daily mean water-level elevation for well 6B, Piceance and Yellow Creek watersheds, Rio Blanco County, Colorado

6. Graph showing methane concentrations in well $6 \mathrm{~B}$ during phase $1,2010-12$, and phase 2, 2013-16, Piceance and Yellow Creek watersheds, Rio Blanco County, Colorado. 
7. Map showing location of geologic structures, faults and fold axes, near the Baro well, 1,500-foot buffer zone around well, Piceance and Yellow Creek

watersheds, Rio Blanco County, Colorado....

8. Graph showing daily mean water-level elevations in relation to time at wells 6A and 6B, water years 2013-16, Piceance and Yellow Creek watersheds, Rio Blanco County, Colorado

9. Graph showing daily mean water-level elevations in relation to time at wells 13U, 13A, and 13B, water years 2013-16, Piceance and Yellow Creek watersheds, Rio Blanco County, Colorado.

\section{Tables}

1. Location, construction, geologic information, and year sampled during phase 2, 2013-16, for wells in the monitoring-well network, Piceance and Yellow Creek watersheds, Rio Blanco County, Colorado.

2. Results of sample blank analysis for study period, 2013-16, Piceance and Yellow Creek watersheds, Rio Blanco County, Colorado.

3. Results of sample replicate analysis for study period, 2013-16, Piceance and Yellow Creek watersheds, Rio Blanco County, Colorado.

4. Field properties and major-ion data for water collected from monitoring wells, 2013-16, Piceance and Yellow Creek watersheds, Rio Blanco County, Colorado.

5. Methane and volatile organic compound concentration data for water collected from monitoring wells, 2013-16, Piceance and Yellow Creek watersheds, Rio Blanco County, Colorado...

6. Hydrocarbon composition, methane isotope, and dissolved methane concentration data for water collected from four monitoring wells, 2013-16, Piceance and Yellow Creek watersheds, Rio Blanco County, Colorado...

7. Nutrient and trace element data for water collected from the Baro well, August 18, 2015, Piceance and Yellow Creek watersheds, Rio Blanco County, Colorado

8. Isotopic data and calculated radiocarbon age for water collected from the Baro well, August 18, 2015, Piceance and Yellow Creek watersheds, Rio Blanco County, Colorado 


\section{Conversion Factors}

U.S. customary units to International System of Units

\begin{tabular}{|c|c|c|}
\hline Multiply & By & To obtain \\
\hline \multicolumn{3}{|c|}{ Length } \\
\hline foot $(\mathrm{ft})$ & 0.3048 & meter $(\mathrm{m})$ \\
\hline mile (mi) & 1.609 & kilometer (km) \\
\hline \multicolumn{3}{|c|}{ Area } \\
\hline square mile $\left(\mathrm{mi}^{2}\right)$ & 2.590 & square kilometer $\left(\mathrm{km}^{2}\right)$ \\
\hline \multicolumn{3}{|c|}{ Volume } \\
\hline gallon (gal) & 3.785 & liter (L) \\
\hline
\end{tabular}

Temperature in degrees Celsius $\left({ }^{\circ} \mathrm{C}\right)$ may be converted to degrees Fahrenheit $\left({ }^{\circ} \mathrm{F}\right)$ as follows:

$$
{ }^{\circ} \mathrm{F}=\left(1.8 \times{ }^{\circ} \mathrm{C}\right)+32 \text {. }
$$

\section{Datum}

Vertical coordinate information is referenced to the North American Vertical Datum of 1988 (NAVD 88).

Horizontal coordinate information is referenced to the North American Datum of 1983 (NAD 83). Altitude, as used in this report, refers to distance above the vertical datum.

\section{Supplemental Information}

Specific conductance is given in microsiemens per centimeter at 25 degrees Celsius $(\mu \mathrm{S} / \mathrm{cm}$ at $\left.25^{\circ} \mathrm{C}\right)$.

Concentrations of chemical constituents in water are given in either milligrams per liter (mg/L) or micrograms per liter $(\mu \mathrm{g} / \mathrm{L})$.

Water year is the 12-month period from October 1 through September 30. The water year is designated by the year in which it ends.

\section{Abbreviations}

DIC dissolved inorganic carbon

USGS U.S. Geological Survey

VOC volatile organic compound 



\title{
Groundwater Chemistry and Water-Level Elevations in Bedrock Aquifers of the Piceance and Yellow Creek Watersheds, Rio Blanco County, Colorado, 2013-16
}

\author{
By Judith C. Thomas and Peter B. McMahon
}

\section{Abstract}

The Piceance and Yellow Creek watersheds in Rio Blanco County, Colorado, are known to contain important energy resources (oil shale and natural gas) and mineral resources (nahcolite). The primary sources of fresh groundwater in the Piceance and Yellow Creek watersheds are bedrock aquifers in the Uinta and Green River Formations. The aquifers are divided into an upper and lower aquifer separated by a regionally extensive semiconfining layer. These aquifers provide water to streams and springs in the watersheds and are an important resource to people living and working in the area. Development of energy and mineral resources has the potential to affect the quality of groundwater in several ways. The Bureau of Land Management and the U.S. Geological Survey began groundwater monitoring in 2010 to characterize the groundwater quality and water-level elevations of shallow bedrock aquifers in the Piceance and Yellow Creek watersheds. The purpose of this report is to present groundwater chemistry and water-level elevations collected during 2013-16. Comparisons are made to data that were collected from the bedrock aquifers from 2010 to 2012 to identify the potential for changes in water quality and water-level elevations.

Appreciable changes in water-level elevations and hydraulic gradient were observed in early April 2015 in two wells completed in the upper and lower aquifers. The hydraulic gradient between the two wells was consistently downward from the upper aquifer to the lower aquifer during 2010-15; however, in early April 2015, the gradient changed from downward to upward between the two aquifers. Overall, water-level elevations declined by about 14 and 11 feet in the upper and lower aquifers, respectively, from 2013 to 2016. Previously published data estimated groundwater ages at 1,200 years old in the upper aquifer and 9,600 years old in the lower aquifer. These groundwater ages indicate that groundwater was recharged over thousands of years. With such long periods of time for aquifer recharge, declines in water-level elevation over short time steps (a few months) have important implications for sustainable management of this resource.
Solution mining activities or drilling for oil and natural gas in the area could be related to the changes observed in waterlevel elevations in these wells; however, further investigation would be needed to evaluate causation.

Changes in major-ion chemistry were evaluated in the bedrock aquifer using time series plots of select major-ion data from 2010 to 2016. Major-ion chemistry was variable for a single well from 2010 to 2016 where alkalinity and sulfate were the most variable constituents. One possible explanation for the observed changes in major-ion chemistry may be that the sample depth for that well no longer represents the most appreciable flow in the borehole. On a larger scale, potential changes in flow within the borehole may indicate changes in the regional flow system. Methane and volatile organic compound concentrations were evaluated using a similar approach to that of major ions and had similar findings. Methane concentrations in wells sampled from 2010 to 2016 were generally constant. The only exception was observed at a single well where the range of methane concentrations was from 57.4 (2010) to 4.02 milligrams per liter (2013). This is the same well where changes in water-level elevation, hydraulic gradient, and major-ion chemistry were observed, providing multiple lines of evidence to indicate change in the bedrock aquifers. Sampling of a well located in an area with little energy development but where faults or fractures could provide a path for the migration of fluids indicate mixing of groundwater between the upper and lower aquifers.

\section{Introduction}

The Piceance and Yellow Creek watersheds in Rio Blanco County, Colorado, are known to contain important energy resources (oil shale and natural gas) and mineral resources (nahcolite) (Dubiel, 2003; Johnson and others, 2010; Brownfield and others, 2010) (fig. 1). Natural gas has been commercially produced in the study area since the 1950 s and continues to the present (2018). The process of drilling for and extracting natural gas has evolved over time from a single well at a single well pad producing natural gas to multiple wells 


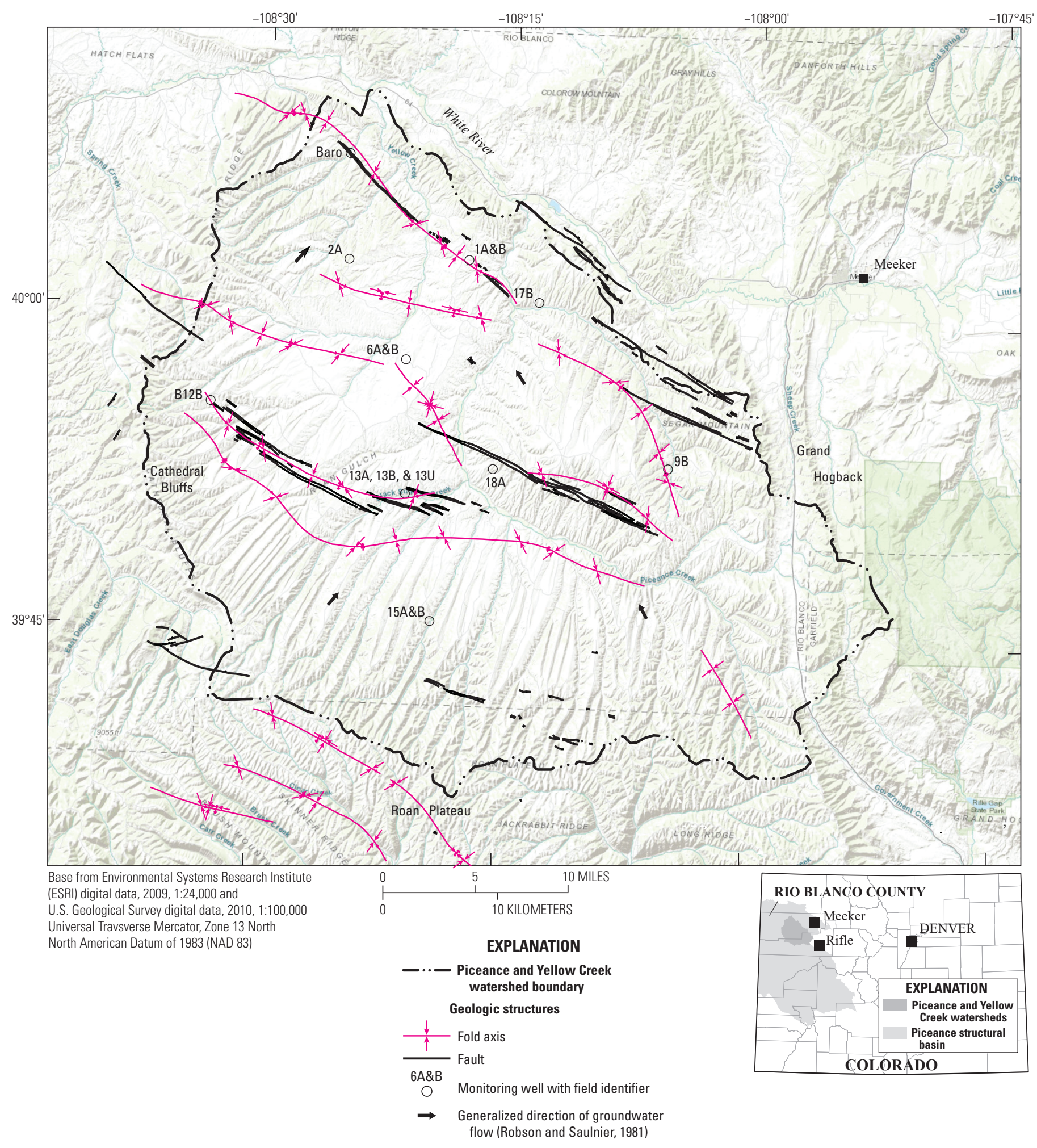

Figure 1. Location of the Piceance Creek and Yellow Creek watersheds in the Piceance structural basin and the location of the monitoring-well network, Rio Blanco County, Colorado (field identifiers from table 1; geologic structure from Hail and Smith [1994, 1997]). 
at a single well pad using directional drilling. In addition, conventional approaches to gas drilling have seen innovation with the use of hydraulic fracturing, which has provided the ability to liberate natural gas from previously unusable formations. Nahcolite has been mined in the study area since 1990 (Brownfield and others, 2010). The process used to extract the nahcolite is solution mining, where hot fluid is injected into the nahcolite-bearing zones to dissolve the nahcolite; then the fluid is subsequently pumped back to the surface to be processed. Primarily, one entity is mining nahcolite in the study area, and in 2013, operations were expanded to double production capacity (Natural Soda, 2017). Oil-shale deposits in the Green River Formation are estimated to contain about 1.5 trillion barrels of oil, making it the richest oil-shale deposit in the world (Johnson and others, 2010); however, there was no commercial-scale development as of 2016.

The primary sources of fresh groundwater in the Piceance and Yellow Creek watersheds are bedrock aquifers in the Uinta and Green River Formations (Weeks and others, 1974). These aquifers provide water to streams and springs in the watershed (Ortiz, 2002) and are an important resource to people living and working in the area. Development of energy and mineral resources has the potential to affect the quality of shallow groundwater in the study area in several ways. Infrastructure associated with the development of energy and mineral resources exists at the land surface throughout the study area and includes pipelines and storage ponds, which if compromised, could contaminate surface water and groundwater, incidents of which have happened in the past 10 years (Finley, 2013; Williams, 2011). Drilling operations can have a direct effect on groundwater, such as the migration of drilling fluids into permeable zones that intersect aquifers. Cement seals of gas wells have the potential to leak, allowing fluids to migrate from depth into shallow aquifers (Watson and Bachu, 2009; King and King, 2013). In addition, natural pathways along faults and fractures allow the migration of fluids from deep reservoirs into shallow aquifers (Johnson and Rice, 1990).

During the 1970s and 1980s, studies of groundwater chemistry and aquifer characterization were completed in relation to proposed oil-shale development (Welder and Saulnier, 1978; Robson and Saulnier, 1981; Slawson and others, 1982; Kimball, 1984). These studies were not meant to address the potential effects of oil and natural gas development or nahcolite mining on the bedrock aquifers. The lack of monitoring (as of 2010) of the bedrock aquifers was identified by the Bureau of Land Management as a data gap that needed to be addressed, and this data gap was formalized in a U.S. Government Accountability Report in 2010 (U.S. Government Accountability Office, 2018). The Bureau of Land Management, White River Field Office, and the U.S. Geological Survey (USGS) began a groundwater monitoring study in 2010 to characterize the groundwater quality of shallow bedrock aquifers in the Piceance and Yellow Creek watersheds. This first phase of monitoring (phase 1, 2010-12) established a monitoring-well network in the study area (McMahon and others, 2013). During phase 1, 14 monitoring wells were sampled for field properties, major ions, nutrients, trace elements, noble gases, dissolved organic carbon, hydrocarbon molecular and isotopic compositions, volatile organic compounds (VOCs), and a broad suite of stable and radioactive isotopes. The chemical and isotopic constituents were selected to provide information on the overall groundwater quality and the occurrence and distribution of chemicals that could be related to the development of underlying reservoirs of oil and natural gas and to better understand groundwater residence times in the flow system. The second phase (phase 2, 2013-16) continues data collection from the monitoring-well network and builds on findings from phase 1. Phase 2 sampling focuses on monitoring groundwater for changes in constituent concentrations, using a smaller number of constituents selected to provide information on the overall groundwater quality, and for the occurrence of chemicals that could be related to the development of underlying oil and gas reservoirs. During phases 1 and 2, continuous water-level elevations were collected in five wells to provide information about temporal variability in water-level elevations and hydraulic gradients in the bedrock aquifers. Monitoring of groundwater from bedrock aquifers provides a tool to help differentiate natural variability in groundwater chemistry and water-level elevations from human-induced changes.

\section{Purpose and Scope}

The purpose of this report is to present groundwater chemistry and water-level elevation data collected from bedrock aquifers in the Piceance and Yellow Creek watersheds during phase 2 (2013-16) of the groundwater monitoring study. Data were compared to previously published data from phase 1 (2010-12) of the study to identify changes in groundwater quality and water-level elevation (McMahon and others, 2013). Monitoring wells completed in the bedrock aquifers were sampled for select chemical constituents to provide information on the overall groundwater quality and to monitor for the occurrence of chemicals that could be related to the development of underlying oil and gas reservoirs. The Baro well was added to the monitoring-well network to evaluate sources and migration pathways of methane and VOCs where faults or fractures could provide a path for the migration of fluids from deep reservoirs to the shallow bedrock aquifers. Continuous water-level elevations were collected at a subset of wells within the monitoring-well network to understand the variability of water-level elevations and hydraulic gradients among bedrock aquifers.

\section{Description of the Study Area}

The study area is the Piceance and Yellow Creek watersheds within the Piceance structural basin in Rio Blanco County, Colo. (fig. 1). The watersheds have a combined area of about 900 square miles and are bounded by the White River to the north and by upland areas to the east (Grand Hogback), 
south (Roan Plateau), and west (Cathedral Bluffs) (fig. 1). Elevations range from about 5,700 feet $(\mathrm{ft})$ at the White River to more than $8,000 \mathrm{ft}$ on the Roan Plateau and Cathedral Bluffs.

The primary bedrock units bearing fresh groundwater are the Uinta Formation and underlying Parachute Creek Member of the Green River Formation. Natural gas is produced primarily below these formations in the Wasatch Formation, Mesaverde Group, and other deeper geologic units (Johnson and Rice, 1990) (fig. 2). The depth of gas wells ranges from
2,500 to $8,000 \mathrm{ft}$ below land surface depending on the geologic unit being targeted (Colorado Oil and Gas Conservation Commission, 2017). For comparison, the depth to the base of the deepest aquifer in the Parachute Creek Member generally is less than about 2,500 ft below land surface.

The geology of the Green River and Uinta Formations has been described in detail in Cashion and Donnell (1974), Hail (1990), Donnell (2009), Brownfield and others (2010), and Johnson and others (2010). Sedimentary strata of the

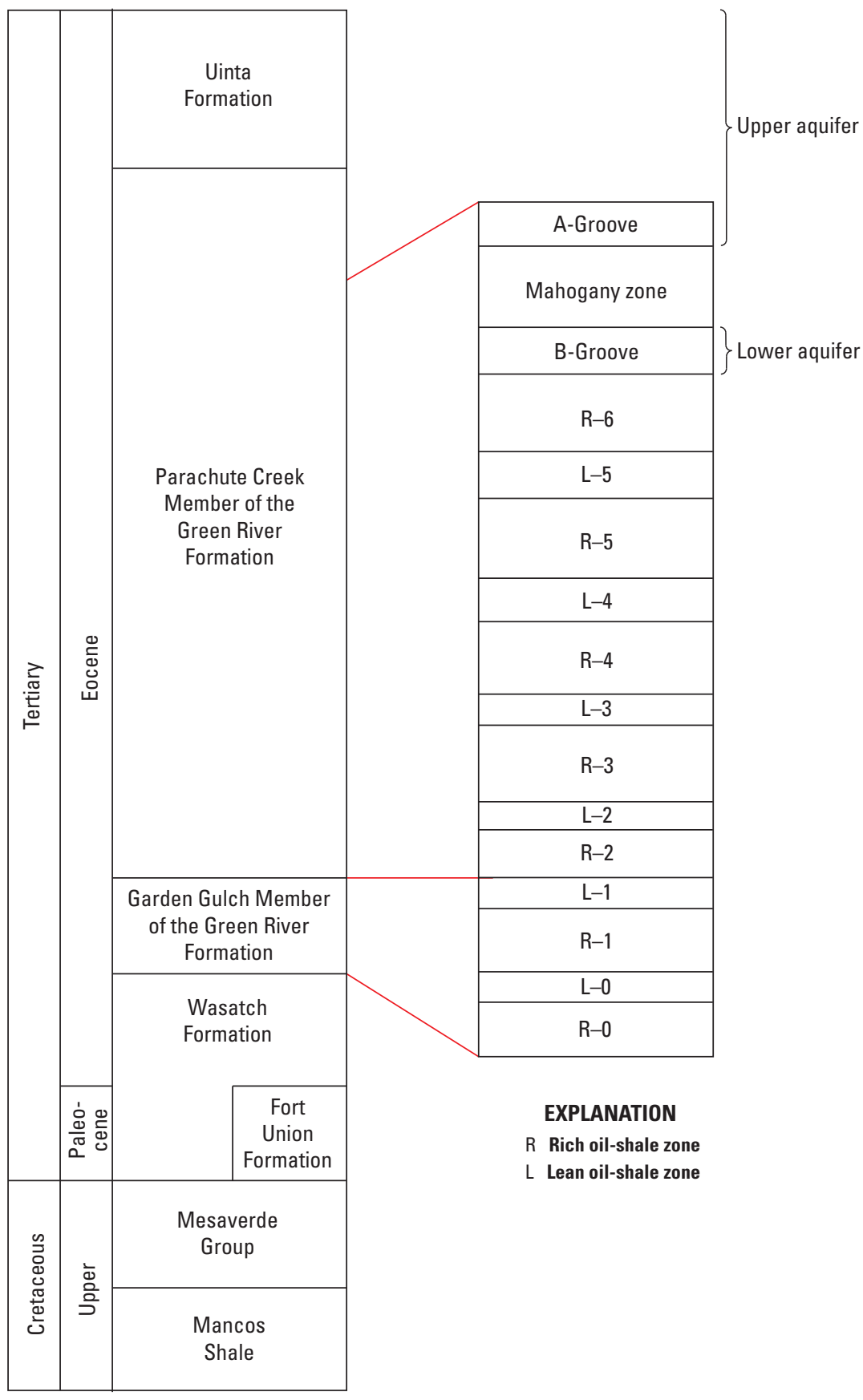

Figure 2. Generalized stratigraphic column for the Piceance and Yellow Creek watersheds within the Piceance structural basin, Rio Blanco County, Colorado (fig. 2 from McMahon and others [2013], modified from Johnson and Rice [1990] and Johnson and others [2010]). 
Parachute Creek Member of the Green River Formation consist of calcareous and dolomitic marlstone, limestone, calcareous sandstone, siltstone, and mudstone with alternating lean and rich oil-shale zones (fig. 2). In the lower parts (L-5 and deeper zones) of the Parachute Creek Member is the saline zone, which contains nahcolite nodules and thin beds that also contain halite (Brownfield and others, 2010). The Uinta Formation overlies the Parachute Creek; however, lower parts of the formation are complexly intertongued with upper parts of the Parachute Creek (Donnell, 2009) (fig. 2). The Uinta Formation is a mix of sandstone, siltstone, mudstone, and marlstone (Johnson, 1981).

The primary sources of porosity and permeability in the Parachute Creek are fractures in the lean zones as well as vugs and breccias from the dissolution of nahcolite (Coffin and others, 1971). The rich oil-shale zones have high kerogen content and thus are more resistant to fracturing than the lean zones (Weeks and others, 1974; Robson and Saulnier, 1981).

A conceptual hydrogeologic model was proposed by USGS in the 1970s that divided the water-bearing zones in the Uinta and Parachute Creek into an upper and lower aquifer system separated by the Mahogany zone in the Parachute Creek Member of the Green River Formation (fig. 2). The Mahogany zone is a regionally extensive semiconfining layer (Coffin and others, 1971; Weeks and others, 1974; Robson and Saulnier, 1981). The upper bedrock aquifer system, consisting of water-bearing rocks of the Uinta and Parachute Creek above the Mahogany zone, has unconfined and confined zones. The lower, mostly confined aquifer system consists of water-bearing rocks of the Parachute Creek below the Mahogany zone and above the saline zone. Permeability of the saline zone and the underlying Garden Gulch Member of the Green River Formation is low, so they form the base of the freshwater-bearing aquifer system.

\section{Methods}

Wells sampled during this study were selected from the monitoring-well network established during phase 1 (McMahon and others, 2013) plus an additional well (Baro well) (table 1). A total of 5 wells were sampled each year of the study, rotating among wells within the monitoring-well network in order to sample all 15 wells at least once during a 3-year period (table 1). Continuous water-level elevations were collected during phase 2 from the same subset of five wells as phase 1 (2013-16; table 1). The following sections provide details on the methods used for well selection, waterquality sample collection, laboratory analysis, quality control, and measurement of water-level elevations.

\section{Monitoring-Well Selection}

Water-quality samples were collected from 5 of the monitoring wells in the monitoring-well network in August 2013, 2015, and 2016 and 2 monitoring wells in 2014, resulting in a total of 17 samples collected from 12 of the wells in the monitoring-well network (table 1). Because of site conditions at the time of sampling and changing data priorities, only 12 of the 15 wells were sampled during phase 2 (table 1). Well B12B was not sampled (table 1) because of changes in the study priorities to resample certain wells to clarify and further investigate findings of previous sample collection. Wells $1 \mathrm{~A}$ and $1 \mathrm{~B}$ were not sampled because road conditions prohibited access. The Baro well was initially supposed to be sampled in 2014; however, road conditions prevented access at that time (table 1).

\section{Sample Collection and Laboratory Analysis}

Samples were collected during phase 2 from wells using either a submersible pump (wells 13A, 13B, and 13U) or a Kemmerer sampler (all other wells) (table 1) using procedures documented in the National Field Manual for the Collection of Water-Quality Data (USGS, 2006). The submersible pumps were made of stainless steel. The Kemmerer sampler is made of stainless steel with silicone seals, has a volume of 1.6 gallons, and was deployed using an electric wireline system and tripod. The Kemmerer sampler was lowered to a specified depth below land surface and then closed. The sample depth was selected using down hole geophysical data collected by USGS in 2011 (McMahon and others, 2013) to identify the depths where water entered and exited the open borehole during nonpumping conditions (Hess, 1986; Molz and others, 1994) (table 1). For wells sampled using a submersible pump, water-quality samples were collected from wells after field properties stabilized (water temperature, $\mathrm{pH}$, dissolved oxygen, and specific conductance), as documented in the National Field Manual for the Collection of Water-Quality Data (USGS, 2006). For samples collected using the Kemmerer sampler, an aliquot of sample water was used to measure field properties. For all samples collected, concentrations of dissolved sulfide and alkalinity were measured in the field. Dissolved sulfide was measured in the field using the methylene blue method (Hach, 2018). Alkalinity was measured in the field by incremental titration using 1.6 normal sulfuric acid (Rounds, 2006).

Different constituents were sampled at different wells based on study priorities. Water samples collected from all wells were analyzed for major ions, dissolved gases (methane, nitrogen, argon, and carbon dioxide), and VOCs. The Baro well was sampled for additional constituents including trace 


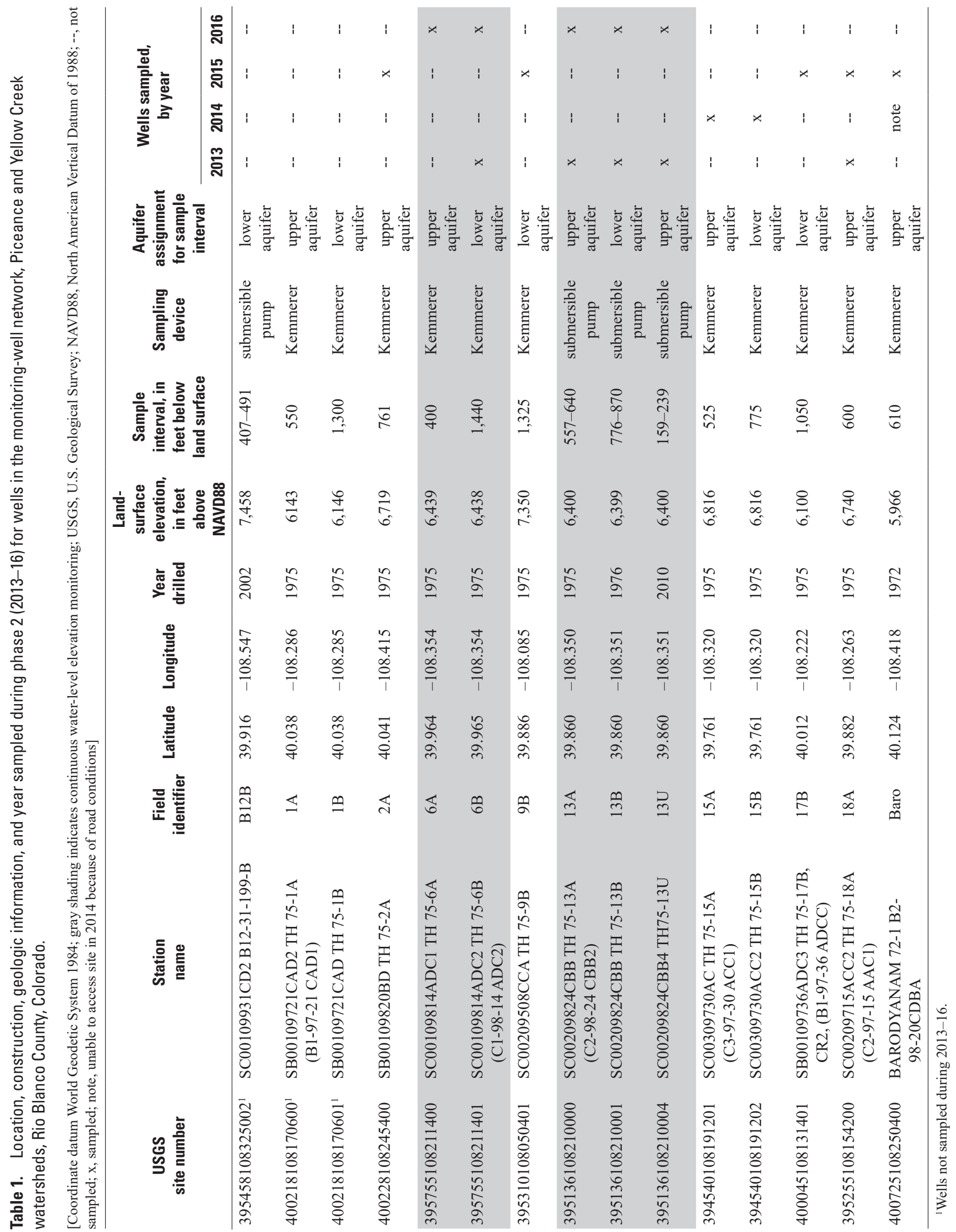


elements, nutrients, dissolved organic carbon, stable isotopes of water $\left(\delta^{2} \mathrm{H}-\mathrm{H}_{2} \mathrm{O}\right.$ and $\left.\delta^{18} \mathrm{O}-\mathrm{H}_{2} \mathrm{O}\right)$, stable carbon isotopes of dissolved inorganic carbon (DIC) $\left(\delta^{13} \mathrm{C}\right.$-DIC), carbon-14 of DIC, and tritium. A total of four wells (13A, 13B, 13U, and Baro well) also were sampled for stable carbon isotope composition $\left(\delta^{13} \mathrm{C}\right)$ of methane (methane isotope), hydrocarbon gas composition, and methane concentrations.

Samples were processed in the field using filtration, acidification, and refrigeration as appropriate based on the constituent and following USGS sample processing procedures (Wilde and others, 2004). Constituents are grouped by preservations (filtration, acidification, and refrigeration) and sampling techniques used. Samples for the analysis of alkalinity, major ions, trace elements, nutrients, dissolved organic carbon, $\delta^{13} \mathrm{C}$-DIC, and carbon-14 of DIC were filtered at the time of collection using a disposable, one-time use, 0.45 -micron capsule filter. All samples were collected in prerinsed, plastic bottles except for VOCs, dissolved organic carbon, $\delta^{13} \mathrm{C}$-DIC, and carbon-14 of DIC, which were collected in baked amber glass bottles. Samples for cation and trace-element analysis were acidified in the field to a $\mathrm{pH}$ of less than 2 using nitric acid. VOC samples were unfiltered and acidified in the field with 1:1 hydrochloric acid. Samples for dissolved organic carbon analysis were acidified in the field using sulfuric acid. Samples for dissolved gases, VOCs, nutrients, and dissolved organic carbon were kept chilled on ice until delivered to the laboratory. Samples for analysis of dissolved gases were unfiltered and collected in glass bottles that were filled and capped with thick rubber stoppers under water to exclude headspace (atmospheric contamination) (USGS, 2017a). Samples for dissolved-gas analysis were collected in duplicate at each well. Samples analyzed for stable isotopes of water $\left(\delta^{2} \mathrm{H}-\mathrm{H}_{2} \mathrm{O}\right.$ and $\delta^{18} \mathrm{O}-\mathrm{H}_{2} \mathrm{O}$ ) were unfiltered and collected in glass bottles with polyseal caps secured with electrical tape (USGS, 2017b). Samples for tritium analysis were unfiltered and collected in plastic bottles with polyseal caps and secured with electrical tape. All data collected are stored in the USGS National Water Information System and available to the public (USGS, 2018).

In presenting constituent analysis, constituents were grouped according to the laboratory completing the analysis. Major ions, VOCs, trace elements, nutrients, and dissolved organic carbon were analyzed using standard methods at the USGS National Water Quality Laboratory in Lakewood, Colo. (Brenton and Arnett, 1993; Fishman, 1993; Fishman and Friedman, 1989; Garbarino and others, 2006; Rose and others, 2016). Concentrations of dissolved gases were measured by the USGS Groundwater Dating Laboratory in Reston, Virginia, using gas chromatography (Busenberg and others, 1993). The USGS Reston Stable Isotope Laboratory in Reston, Va., analyzed samples for $\delta^{2} \mathrm{H}-\mathrm{H}_{2} \mathrm{O}$ and $\delta^{18} \mathrm{O}-\mathrm{H}_{2} \mathrm{O}$ (Révész and Coplen, 2008a and 2008b). Hydrogen and oxygen isotopes in water were reported relative to Vienna Standard Mean Ocean Water. All isotope results were reported using the standard delta notation $(\delta)$, in per mil (o/oo, parts per thousand); for example, $\delta^{18} \mathrm{O}-\mathrm{H}_{2} \mathrm{O}$ is defined as the following:

$$
\left.\delta^{18} \mathrm{O}-\mathrm{H}_{2} \mathrm{O}=\left(\left[{ }^{18} \mathrm{O} /{ }^{16} \mathrm{O}\right]_{\text {sample }} /{ }^{18} \mathrm{O} /{ }^{16} \mathrm{O}\right]_{\text {ref }}-1\right) \times 1,000
$$

where

$$
\begin{aligned}
& { }^{18} \mathrm{O} /{ }^{16} \mathrm{O} \quad \text { is the ratio of oxygen- } 18 \text { to oxygen-16 in } \\
& \text { the sample and reference (ref) material } \\
& \text { (Vienna Standard Mean Ocean Water in } \\
& \text { this example). }
\end{aligned}
$$

The $\delta^{13} \mathrm{C}$-DIC and carbon-14 of DIC samples were measured at the Woods Hole Oceanographic Institution, National Ocean Sciences Accelerator Mass Spectrometry facility (Woods Hole Oceanographic Institution, 2018). The $\delta^{13} \mathrm{C}$-DIC results are reported relative to Vienna Peedee belemnite, and the carbon-14 of DIC results are reported in percent modern carbon. Radiocarbon age was calculated from the $\delta^{13} \mathrm{C}$ corrected fraction modern according to the following formula:

$$
\text { Age }=-8,033 \ln (F m)
$$

where

$$
\begin{aligned}
\ln & \text { is the natural } \log \text { and } \\
F m & \text { is the } \delta^{13} \mathrm{C} \text { fraction modern. }
\end{aligned}
$$

The reporting of ages and activities follows the conventions outlined by Stuiver and Polach (1977) and Stuiver (1980). Tritium analyses were completed at USGS Noble Gas Laboratory in Denver, Colo., and reported in tritium units (TU) (Bayer and others, 1989).

A total of four wells were sampled for stable carbon isotope composition $\left(\delta^{13} \mathrm{C}\right)$ of methane (methane isotope), hydrocarbon gas composition, and methane concentrations. These samples were collected using an IsoFlask ${ }^{\circledR}$ obtained from Isotech Laboratories, Inc., Champaign, Illinois (Isotech Laboratories, Inc., 2018a). Instructions for filling IsoFlasks ${ }^{\circledR}$ are provided by Isotech Laboratories, Inc. Filled IsoFlasks ${ }^{\circledR}$ were placed in a protective box lying flat and shipped overnight to Isotech Laboratories for analysis. Stable carbon isotope compositions of gas components were determined by chromatographic separation followed by combustion and dual-inlet isotope ratio mass spectrometry (Isotech Laboratories, Inc., 2018b). Chromatographic determination was used to determine hydrocarbons, and dissolved methane concentration was calculated using a head-space equilibration method (Isotech Laboratories, Inc., 2018c).

\section{Quality Control}

Quality-control data were collected during each sampling event and included a field blank and a sequential replicate, except during 2013 where only a replicate sample was collected (tables 2 and 3), following USGS procedures (USGS, 2006). Field blanks were collected to evaluate potential sample contamination related to sample collection, handling, and equipment cleaning under field conditions and 


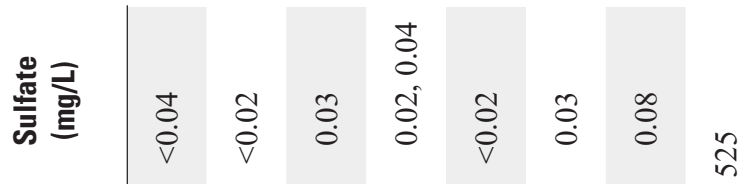

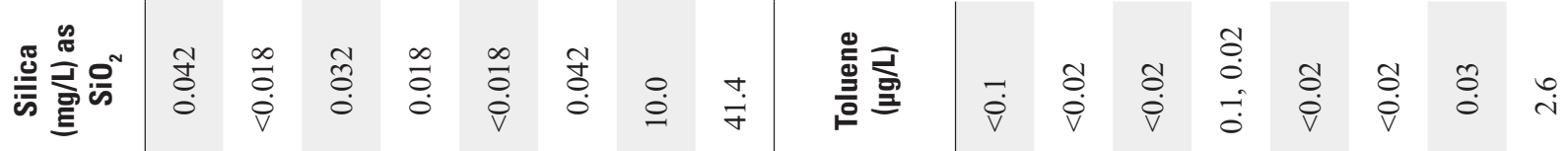

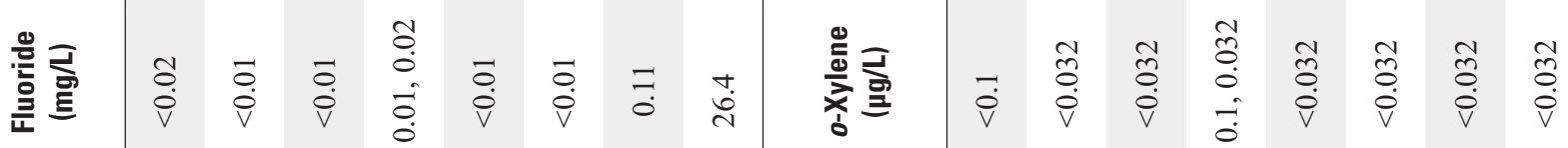

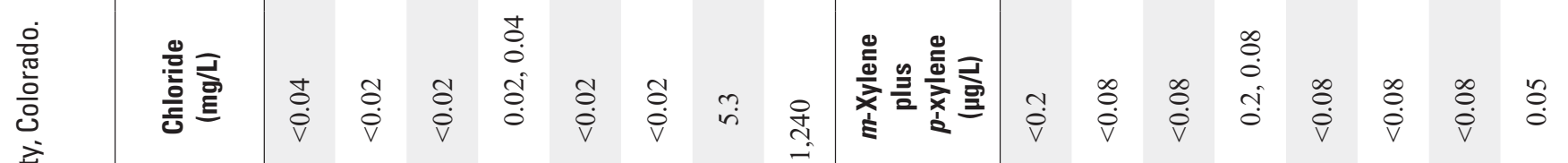

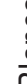

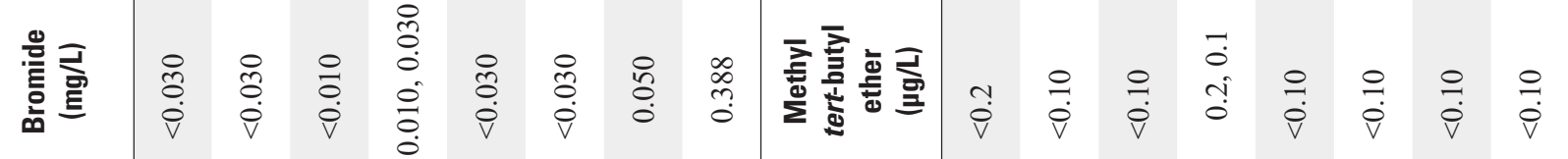

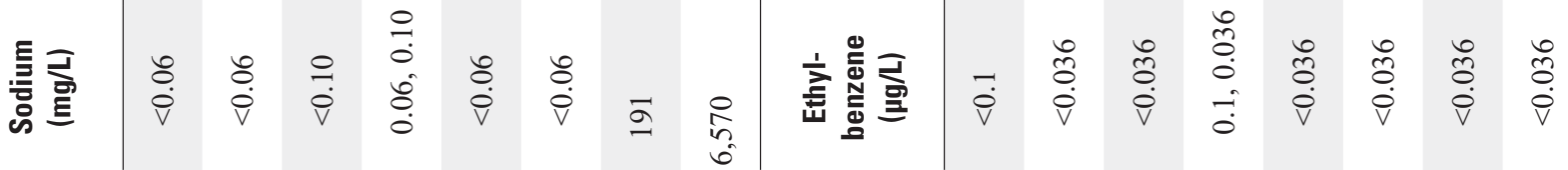

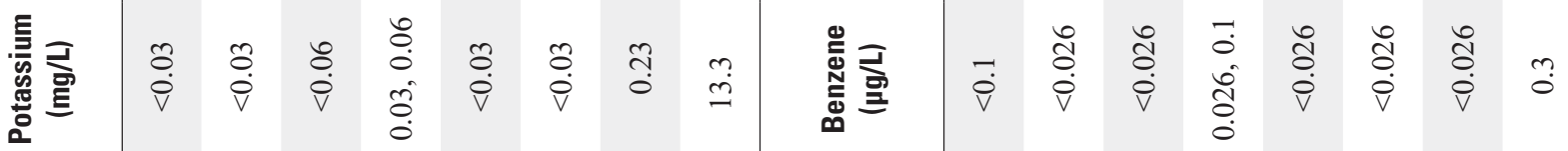

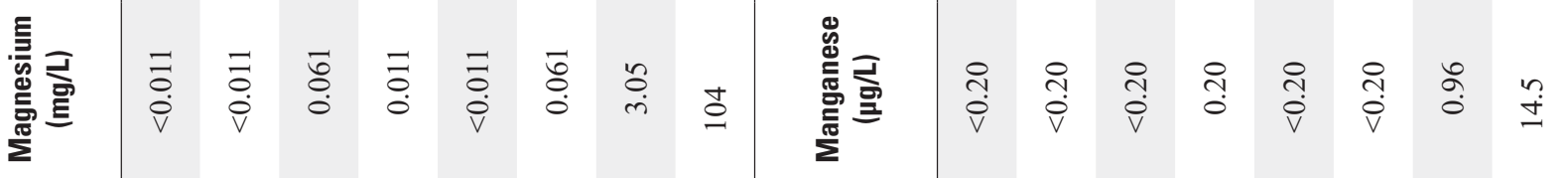

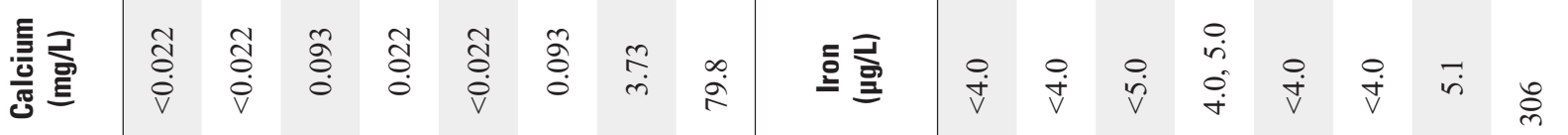

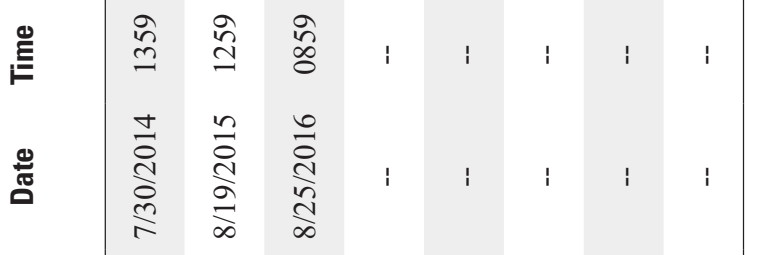

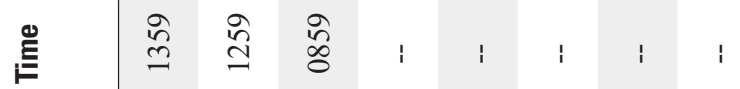

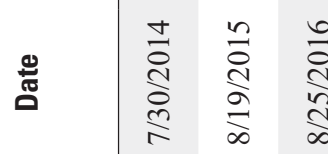
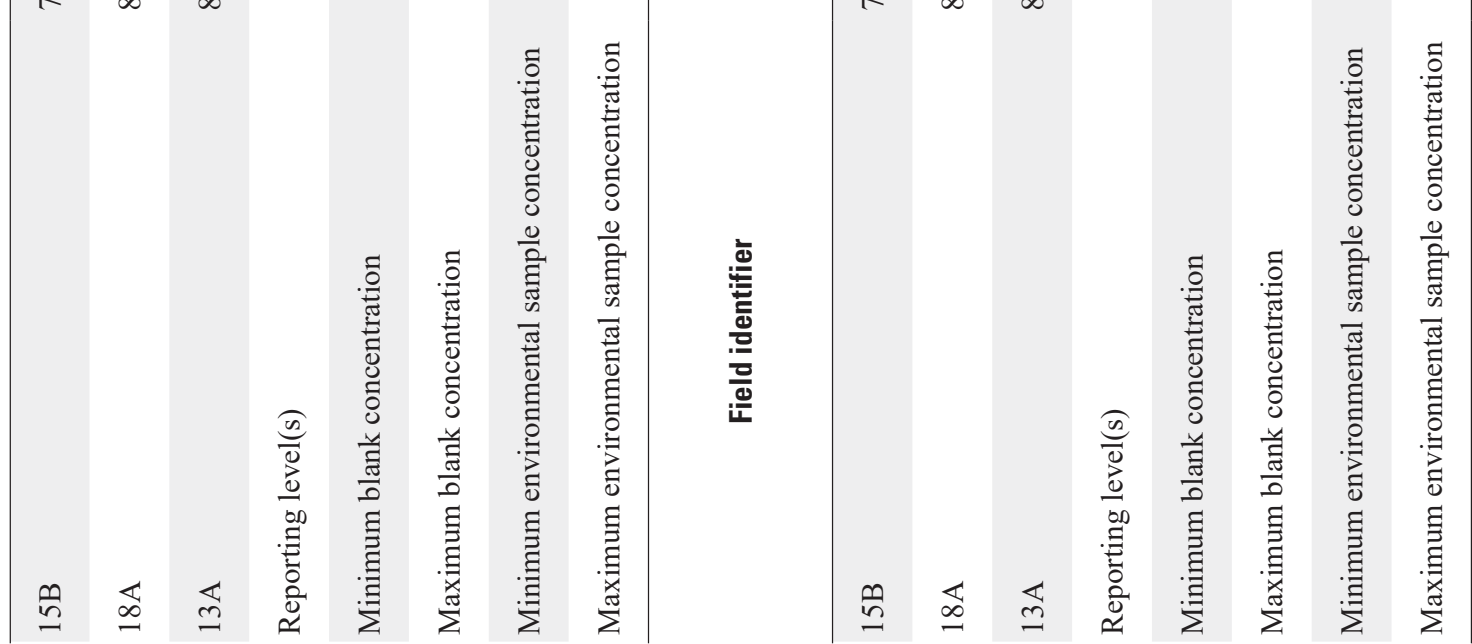
Table 3. Results of sample replicate analysis for study period, 2013-16, Piceance and Yellow Creek watersheds, Rio Blanco County, Colorado.

$\left[\mathrm{mg} / \mathrm{L}\right.$, milligram per liter; $\mathrm{SiO}_{2}$, silicon dioxide; $\mu \mathrm{g} / \mathrm{L}$, microgram per liter; relative percent difference, the absolute difference between replicate analyses divided by the average of the analyses and expressed as percent; $<$, less than; --, no data]

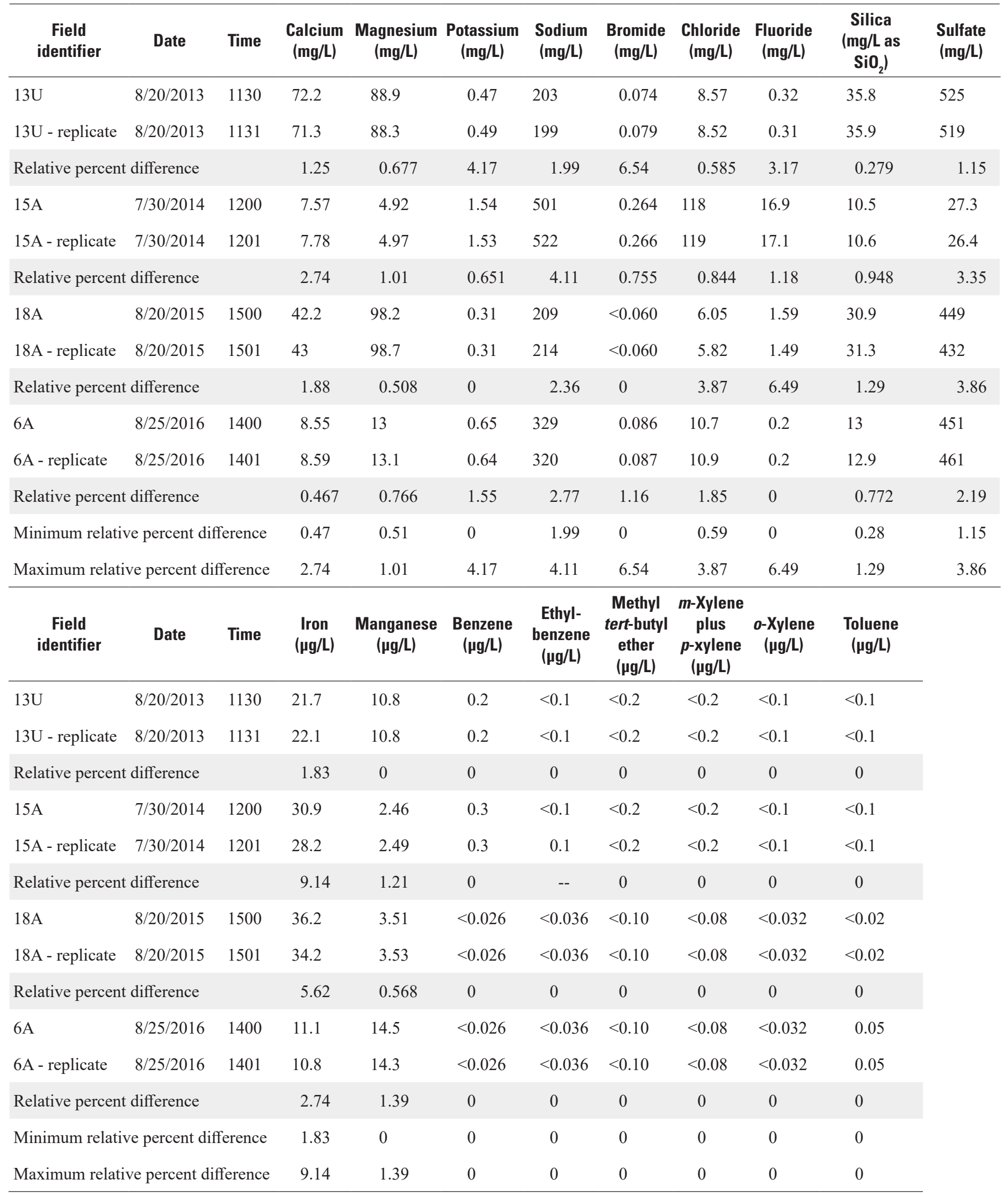


were analyzed for major ions and VOCs. Few constituents were detected in field blanks, and detections were less than minimum environmental sample concentrations except for $m$-xylene plus $p$-xylene where the maximum environmental sample concentration was 0.05 micrograms per liter $(\mu \mathrm{g} / \mathrm{L})$, which is below the laboratory reporting level but above the long-term method detection level (table 2). Sequential replicate samples were collected for major ions and VOC's immediately after environmental samples to assess analytical variability and variability resulting from sample collection. Analysis of replicate samples indicated that most constituents had relative percent differences of less than 5 percent, and all constituents had relative percent differences below 10 percent (table 3).

Charge balance was used to evaluate sample quality by determining the difference in milliequivalents between the cations and anions for each environmental sample. Milliequivalent balances were calculated according to methods described by Hem (1985). Charge balances for all but one sample were between 5 and 10 percent, indicating generally good analytical results for major ions.

\section{Measurement of Water-Level Elevations}

A discrete water level (depth to water in $\mathrm{ft}$ below land surface) was measured in wells at the time of sample collection using either a steel tape or an electric tape, following USGS procedures (Cunningham and Schalk, 2011). The waterlevel elevation was determined by subtracting the measured depth to water in $\mathrm{ft}$ below land surface (table 4) from the land-surface elevation above North American Vertical Datum of 1988 at each well location (table 1). Continuous water-level elevations were collected at five wells in the monitoring-well network to provide information on changes in water-level elevations and hydraulic gradients between the upper and lower aquifers (table 1). Continuous water-level elevations were measured using nonvented pressure transducers. Pressure readings were corrected for fluctuations in barometric pressure using data from a barometric pressure sensor (Cunningham and Schalk, 2011). Continuous water-level elevations in this report are presented as daily mean values by water year (a water year is the 12-month period from October 1 through September 30 and is designated by the year in which it ends) and processing of the measured data followed USGS guidelines (Freeman and others, 2004). All water-level elevations (discrete and continuous) are available from the National Water Information System (USGS, 2018).

\section{Groundwater Chemistry and Water- Level Elevations in Bedrock Aquifers}

The following sections of the report describe the results of groundwater monitoring. The sections on reduction-oxidation (redox) processes, major-ion chemistry, and methane and VOCs describe the conditions observed during phase 2 (2013-16) and comparison to observations and data presented from phase 1 (McMahon and others, 2013). Within the section on redox, concentrations of dissolved oxygen, methane, dissolved sulfide, sulfate, and methane isotopes are discussed as they pertain to redox. The section on the Baro well describes the reasons for the addition of this well into the monitoringwell network and the results and implications from this well. Continuous water-level elevations were used to identify appreciable changes in water-level elevation and to understand hydraulic gradients between the upper and lower aquifers.

\section{Reduction-0xidation Processes}

Reduction-oxidation (redox) processes involve the transfer of electrons from one chemical species to another. Electron acceptors are reduced, and electron donors are oxidized. Dissolved oxygen, when present, is the preferred electron acceptor because the reduction of oxygen produces more energy than any other common electron acceptor (McMahon and Chapelle, 2008). Groundwater containing at least 0.5 milligrams per liter $(\mathrm{mg} / \mathrm{L})$ of dissolved oxygen is considered to be oxic, whereas anoxic groundwater contains less than $0.5 \mathrm{mg} / \mathrm{L}$ of dissolved oxygen. Anoxic conditions existed for all samples collected during phase 2 , as evidenced by dissolved oxygen concentrations less than $0.5 \mathrm{mg} / \mathrm{L}$ (table 4).

Sulfate reduction and methanogenesis were important redox processes in anoxic groundwater in the study area based on the presence of dissolved sulfide (table 4) and methane (table 5) in water from several wells. The inverse relation observed between methane and sulfate (fig. 3) likely results from sulfate-reducing microbes outcompeting methanogens for electron donors needed to support their metabolism (Lovley and Klug, 1986). This relation appears in all samples except samples from well 13U, where high sulfate concentrations were present with high methane concentrations (fig. 3). As McMahon and others (2013) observed during phase 1, samples from well $13 \mathrm{U}$ consisted almost entirely of thermogenic methane. Methane isotope data collected during phase 2 


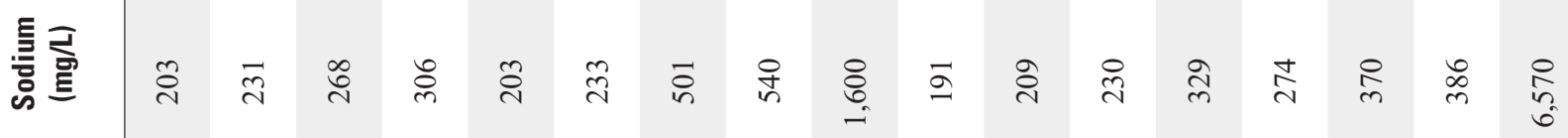

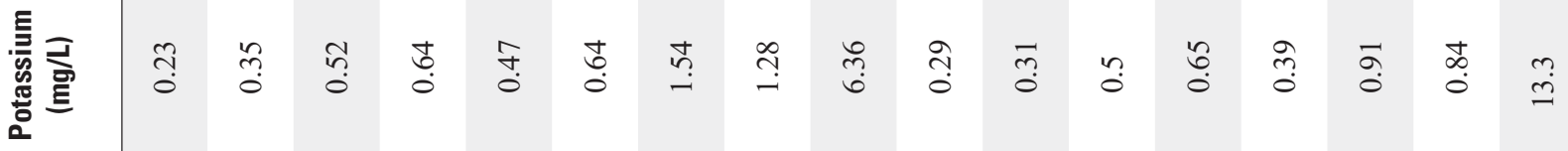

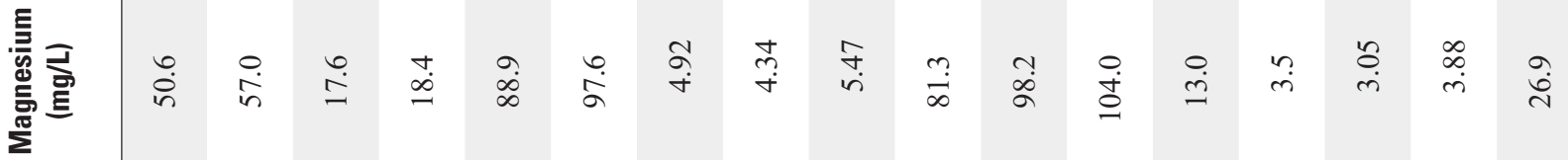

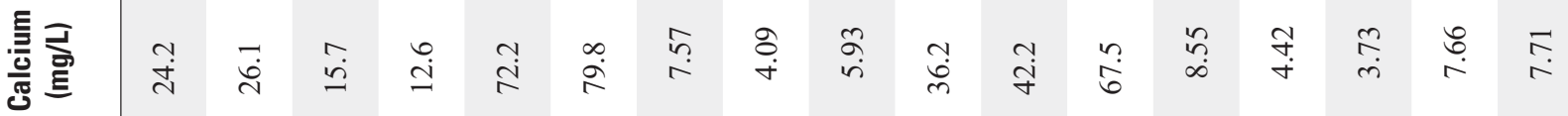

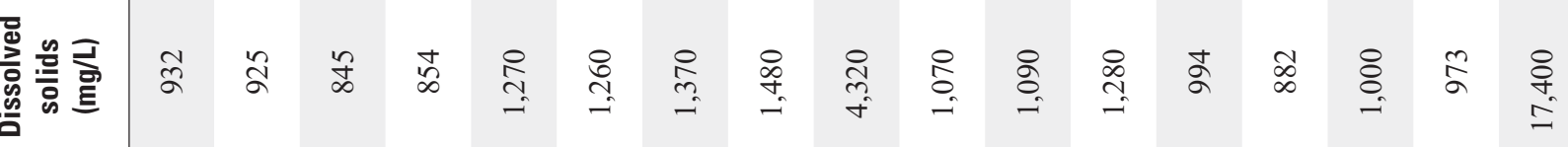

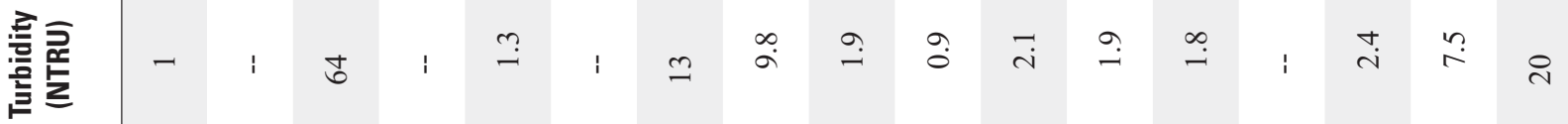

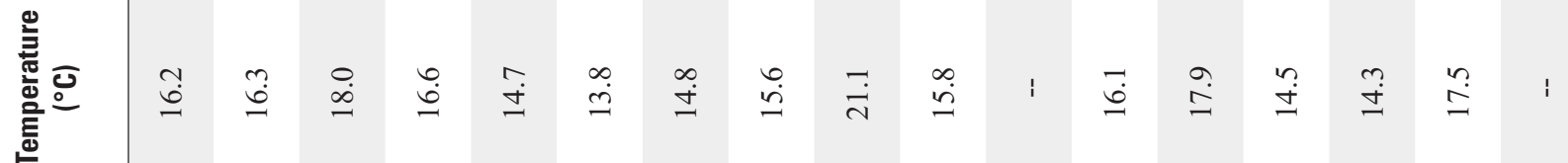

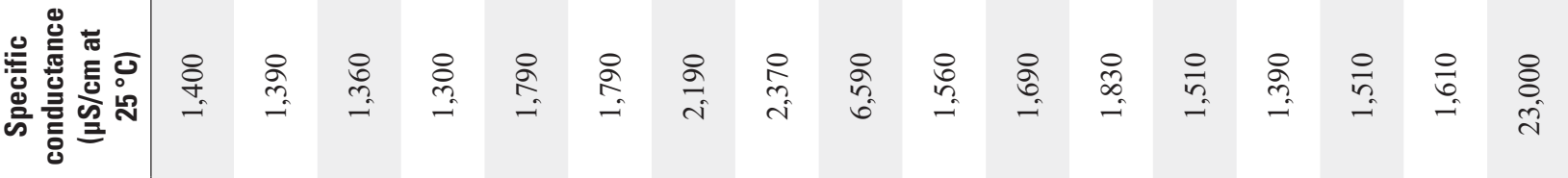

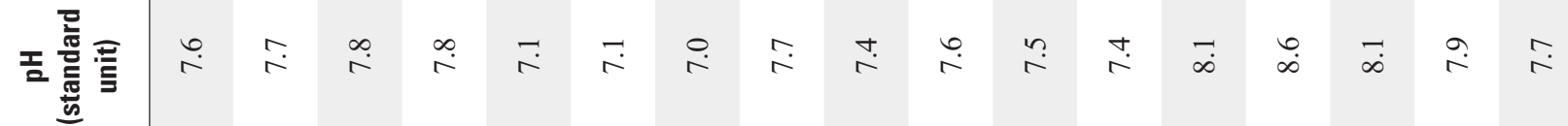

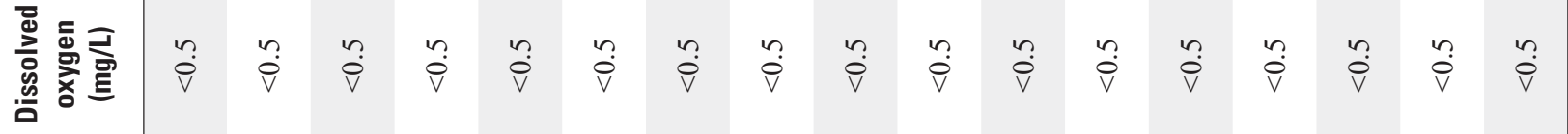

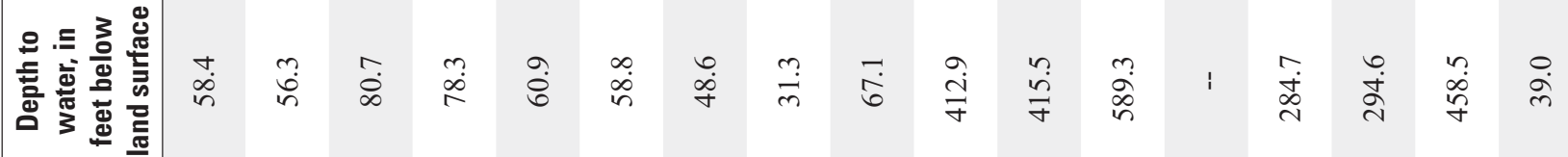

苂

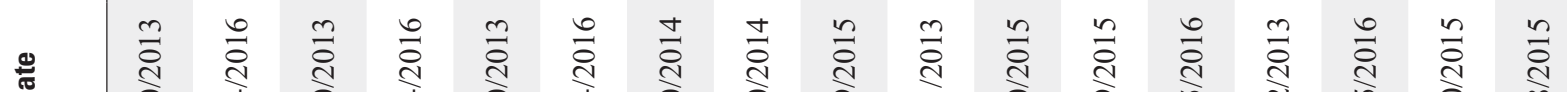

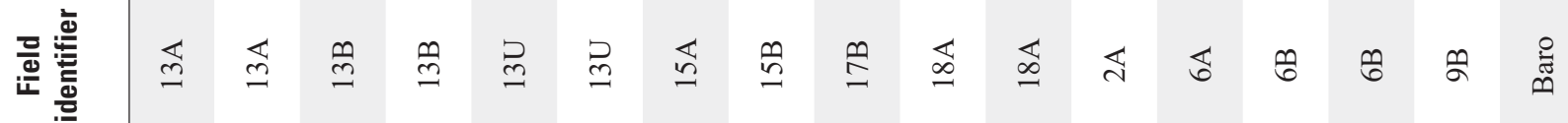




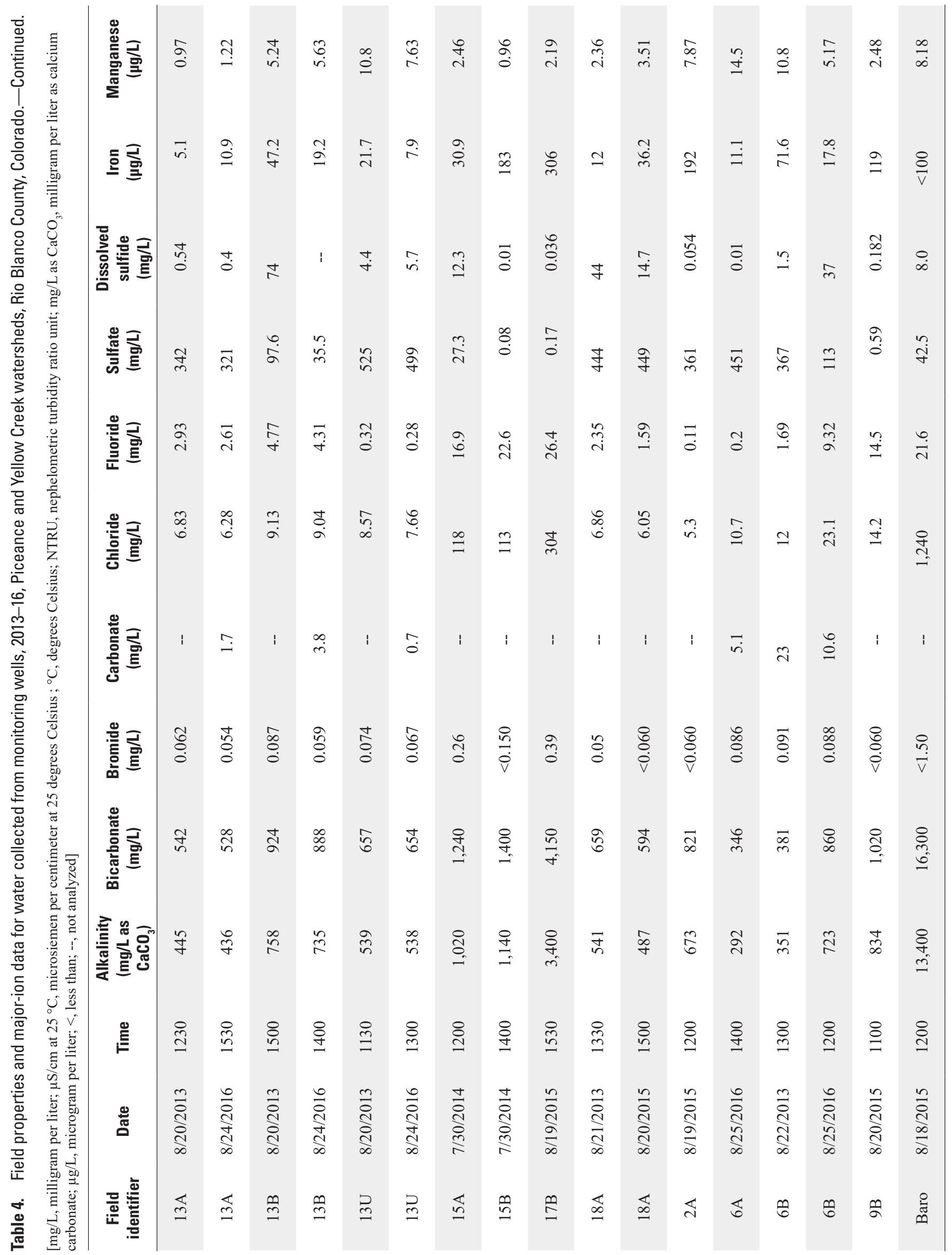




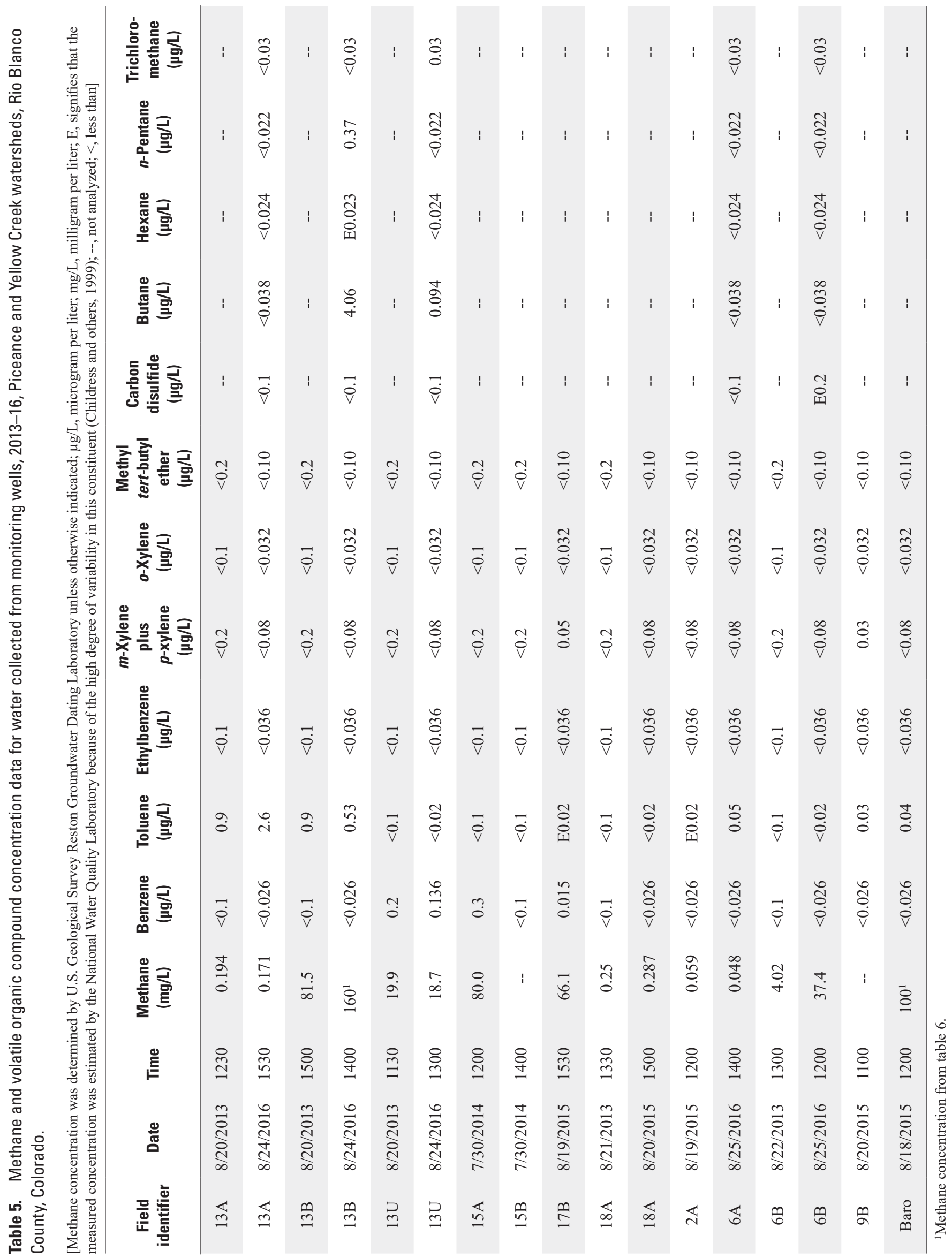




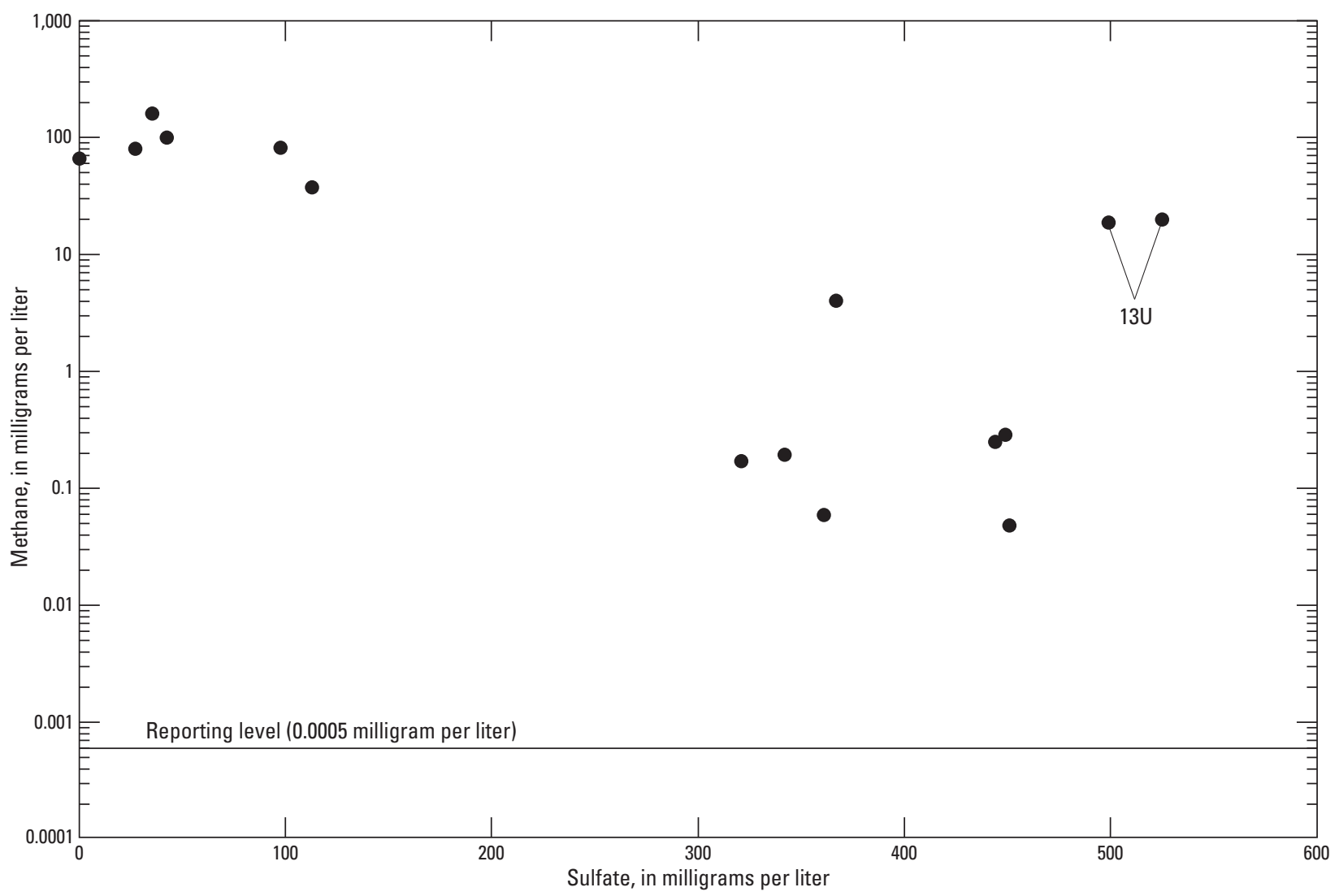

EXPLANATION

- Methane concentration from monitoring wells

Figure 3. Methane concentrations in relation to sulfate concentrations for water samples collected from monitoring wells, 2013-16, Piceance and Yellow Creek watersheds, Rio Blanco County, Colorado.

(table 6) are consistent with phase 1 findings (fig. 6 of McMahon and others, 2013). The combination of isotope data and sulfate and methane concentration data indicate that biogenic processes are not a primary control on methane concentrations in well $13 \mathrm{U}$.

\section{Major-Ion Chemistry}

Major-ion chemistry is the principal contributor of electrical charge for dissolved constituents in water and is used to define water types (Hem, 1985). Concentrations of dissolved solids in water samples ranged from 845 to $17,400 \mathrm{mg} / \mathrm{L}$ (table 4). The highest concentrations were in samples from well 17B (4,320 mg/L) and the Baro well (17,400 mg/L), which were in the regional discharge area at the northern end of the study area (fig. 1). Based on sample composition in percentage of milliequivalents per liter, water types for all samples were generally mixed cation-bicarbonate-sulfate and sodium-bicarbonate water types (fig. 4). McMahon and others (2013) observed that these two water types indicate the evolution of groundwater along its flow path where the mixed cation-bicarbonate-sulfate water type represents water closer to its recharge areas in higher topographic locations in the study area. The sodium-bicarbonate water type represents water that has traveled farther along its flow path toward the regional groundwater discharge area in the northern part of the study area (McMahon and others, 2013). Wells 13A, 13B, $13 \mathrm{U}, 18 \mathrm{~A}$, and $6 \mathrm{~B}$ were sampled twice during phase 2 , where the two samples from each well plot relatively close to one another on the trilinear diagram except for 6B. Well 6B cations did not change for the two samples collected during phase 2, but anions were a mix of bicarbonate and sulfate during the 2013 sample and almost entirely bicarbonate during the 2016 sample (table 4, fig. 4).

Time series plots of select major-ion data were evaluated from phase 1 (table 2 of McMahon and others [2013]) and phase 2 (table 4) to further understand potential changes in major-ion chemistry. Well 6B was the only site with variable major-ion chemistry where alkalinity and sulfate were the most variable constituents, and these changes in chemistry do not seem to correspond to appreciable changes in water-level elevations (fig. 5). Well 6B was sampled using the Kemmerer 
Table 6. Hydrocarbon composition, methane isotope, and dissolved methane concentration data for water collected from four monitoring wells, 2013-16, Piceance and Yellow Creek watersheds, Rio Blanco County, Colorado.

[All results were determined by Isotech Laboratories Inc.; $\delta^{13} \mathrm{C}$, stable carbon isotope composition; per mil, part per thousand; mg/L, milligram per liter; --, not analyzed]

\begin{tabular}{cccccc}
\hline $\begin{array}{c}\text { Field } \\
\text { identifier }\end{array}$ & Date & Time & $\begin{array}{c}\text { Methane/ } \\
\text { (ethane + propane) }\end{array}$ & $\begin{array}{c}\delta^{13} \text { C of methane, } \\
\text { in per mil }\end{array}$ & Dissolved methane (mg/L) \\
\hline Baro & $8 / 18 / 2015$ & 1200 & 1,267 & -67.17 & 100 \\
$13 \mathrm{~A}$ & $8 / 24 / 2016$ & 1530 & 175.4 & -- & 0.13 \\
$13 \mathrm{U}$ & $8 / 24 / 2016$ & 1300 & 29.01 & -34.06 & 17 \\
$13 \mathrm{~B}$ & $8 / 24 / 2016$ & 1400 & 929.6 & -62.38 & 160 \\
\hline
\end{tabular}

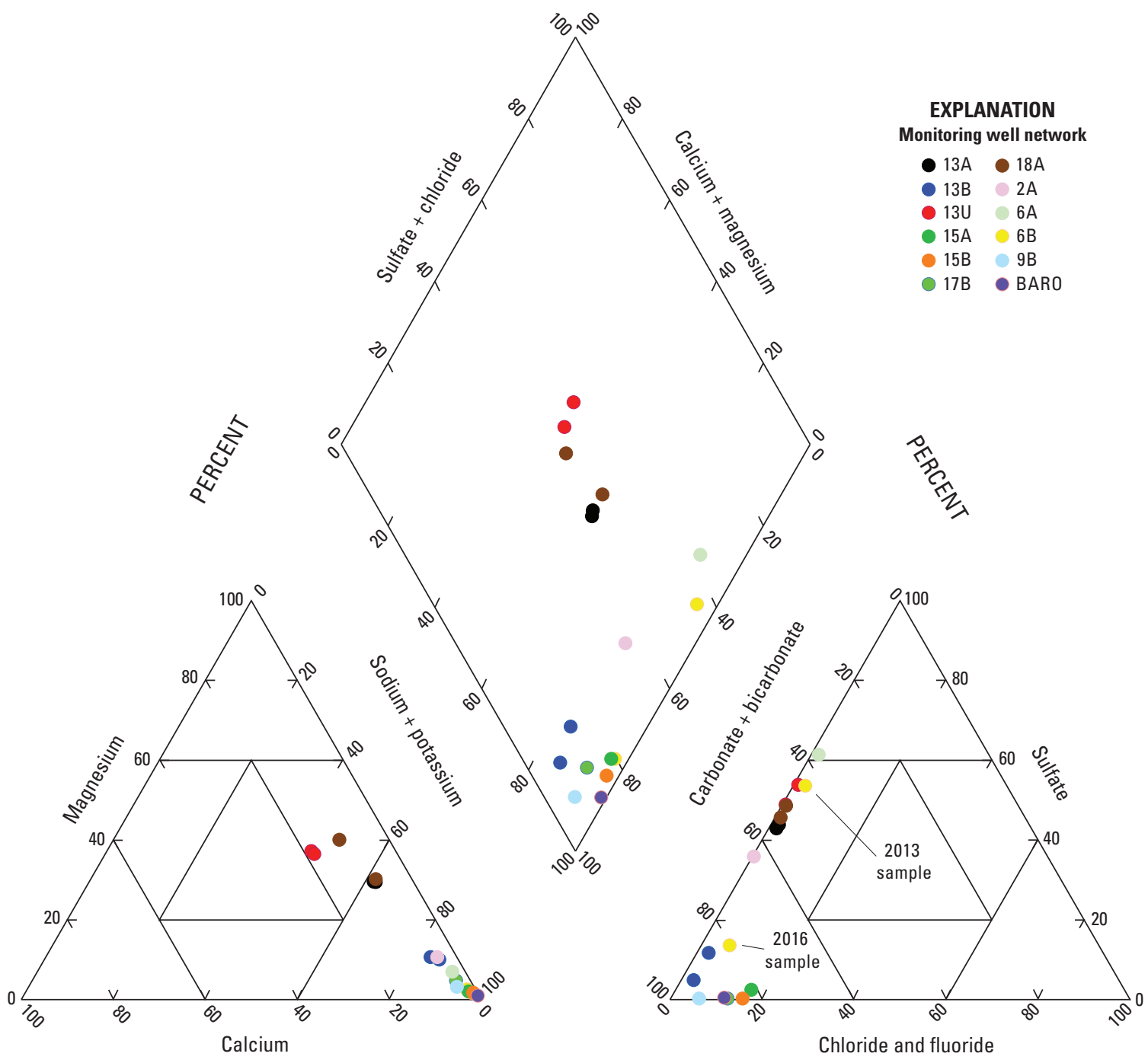

PERCENT

Figure 4. Trilinear diagram showing water composition, in percent of constituents, collected from monitoring wells, 2013-16, Piceance and Yellow Creek watersheds, Rio Blanco County, Colorado. 


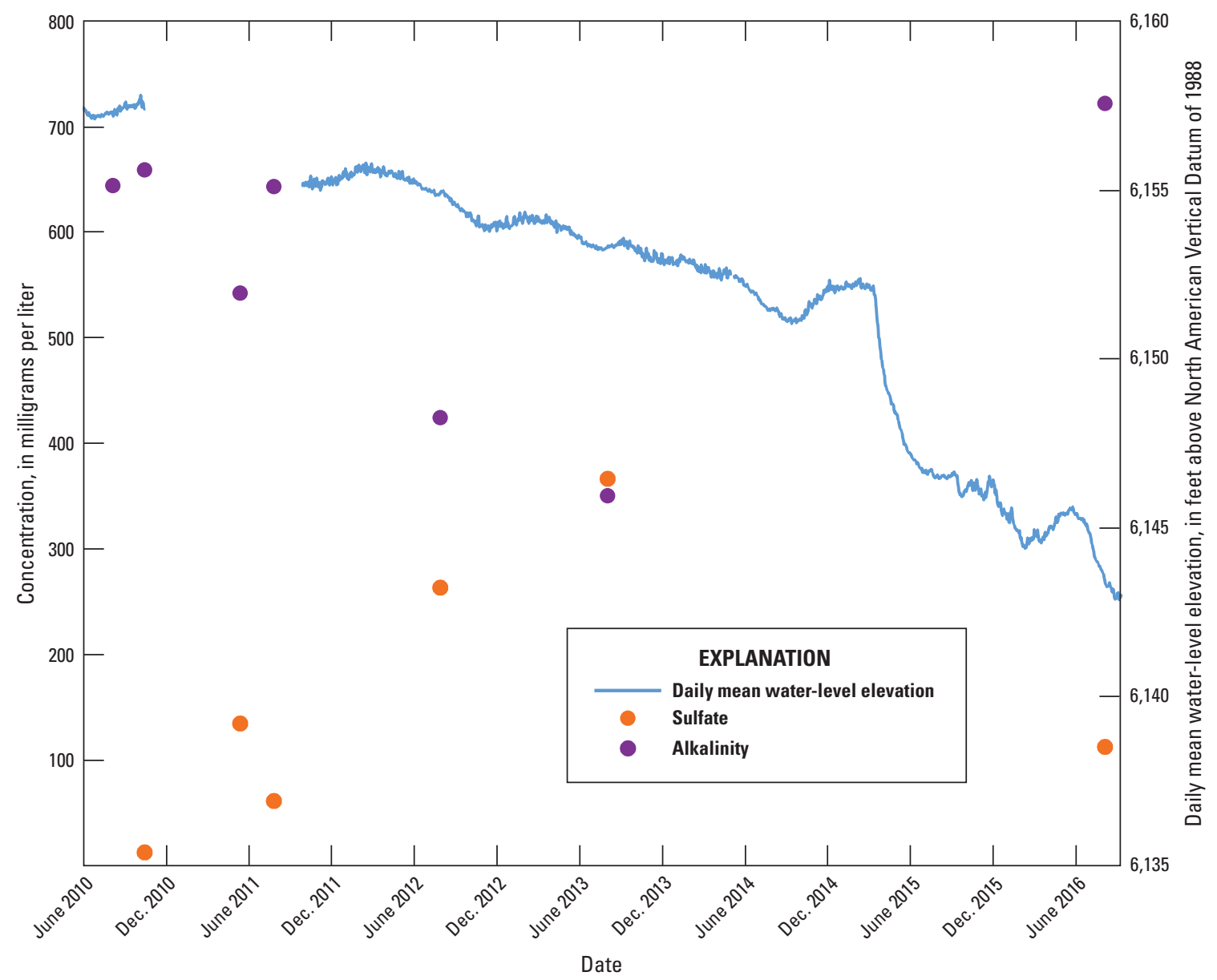

Figure 5. Time series plot of alkalinity and sulfate concentration data collected during phase 1 and phase 2 with daily mean water-level elevation for well 6B, Piceance and Yellow Creek watersheds, Rio Blanco County, Colorado.

sampler for all sampling events where the sampler was lowered to a depth of 1,440 ft below land surface for sample collection (table 1). One possible explanation for the observed changes in major-ion chemistry may be that the sample depth used for well $6 \mathrm{~B}$ no longer represents the most appreciable flow in the borehole. On a larger scale, these changes in flow within the borehole may indicate changes in the regional flow system.

\section{Methane and Volatile Organic Compounds}

Methane concentrations in groundwater collected during phase 2 ranged from 0.048 to $160 \mathrm{mg} / \mathrm{L}$ (table 5). Although there is no Federal drinking-water standard for methane, methane concentrations greater than $28 \mathrm{mg} / \mathrm{L}$ could result in an immediate explosive hazard if methane degassed from pumped groundwater in a confined space such as a well bore, well house, or basement (Eltschlager and others, 2001). A total of five wells sampled during phase 2 had methane concentrations greater than $28 \mathrm{mg} / \mathrm{L}$ (table 5). Well 13B was sampled twice during phase 2 , and both samples had methane concentrations greater than $28 \mathrm{mg} / \mathrm{L}$. Methane concentrations in wells sampled during phases 1 (table 4 of McMahon and others [2013]) and 2 (table 5) were generally consistent with the exception of well $6 \mathrm{~B}$, where methane concentrations were $57.4 \mathrm{mg} / \mathrm{L}$ in 2010 and $4.02 \mathrm{mg} / \mathrm{L}$ in 2013 (fig. 6). Like the variability observed in major-ion chemistry, variability in methane concentrations in well $6 \mathrm{~B}$ may be the result of changes to flow in the borehole, which imply changes in the regional flow system.

During 2016, laboratory detection levels were lowered and analyses were expanded to increase the number of VOCs that were analyzed, which resulted in an increased frequency of VOC detections (table 5). Compared to results from phase 1 (table 4 of McMahon and others [2013]), toluene was detected more often during phase 2 and in more wells (table 5). Benzene was detected in samples from 3 wells during phase 2 (13U, 15A, and 17B) (table 5), 2 of which had benzene detections during phase 1 (15A and 13U) (table 4 of McMahon and others [2013]) and 1 new detection (17B), owing to the change in detection limit. Xylene (meta $[m]$ and para $[p]$ isomers) was not detected in any well during phase 1 , but it was detected 


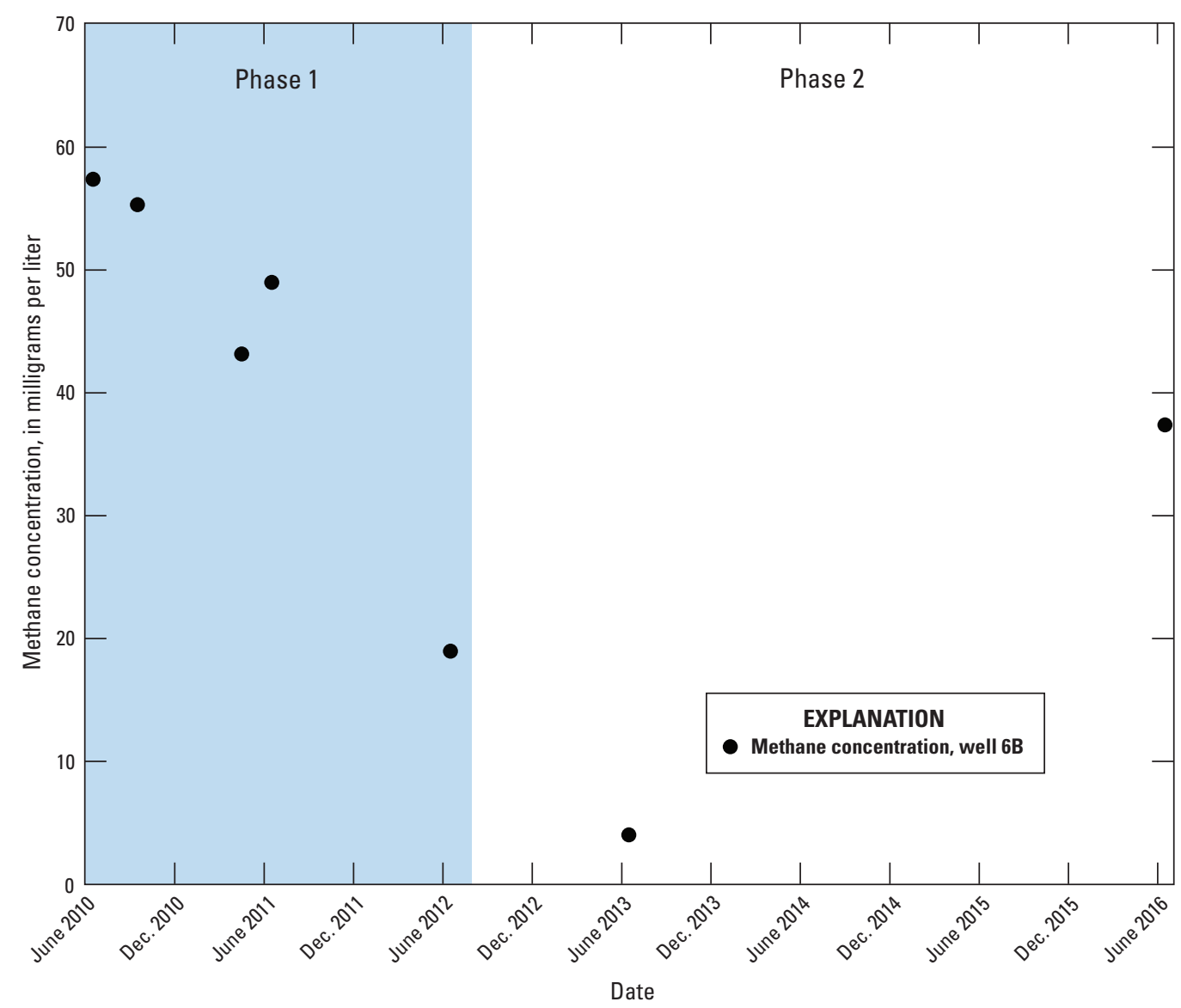

Figure 6. Methane concentrations in well 6B during phase 1 (2010-12) and phase 2 (2013-16), Piceance and Yellow Creek watersheds, Rio Blanco County, Colorado.

during phase 2 in samples from wells 17B and 9B. Ethylbenzene was detected once during phase 1 in a sample from well 15A (table 4 of McMahon and others [2013]), and had no detections during phase 2 (table 5). Additional constituents detected as part of the expanded constituent list included carbon disulfide (6B), butane (13B and 13U), hexane (13B), n-pentane (13B), and trichloromethane (13U), which is commonly known as chloroform (table 5). Butane, hexane, and n-pentane in the shallow bedrock aquifers indicate a mixing with deeper groundwater (Warner and others, 2012). Detections of these compounds were at low concentrations but provided indication of the widespread and persistent occurrence of select VOCs in the shallow bedrock aquifers.

\section{Baro Well}

One recommendation from McMahon and others (2013) was to evaluate sources and migration pathways of methane and VOCs in the study area by sampling a well where there was little energy development but where faults or fractures could provide a path for the migration of fluids from deep reservoirs to the shallow bedrock aquifers (fig. 7). The Baro well was selected for addition into the monitoring-well network based on these criteria. The well is in the Greasewood Creek drainage, which is tributary to Yellow Creek (fig. 7). Based on geophysical data and interpretation by Shell Exploration and Production Company, the well is completed primarily in the Uinta Formation in the upper aquifer (Day and others, 2010). The depth to water below land surface is $39.0 \mathrm{ft}$ (table 4), and the well itself is in the northern part of the study area, which is considered the regional groundwater discharge area. Dissolved solids concentrations were 17,400 mg/L, the highest measured during phase 2 (table 4). Major-ion data indicate the Baro well had a sodium-bicarbonate water type similar to well 17B (fig. 4). Well 17B also is in the northern part of the study area but completed in the lower aquifer. Fluoride concentrations in the Baro well were $21.6 \mathrm{mg} / \mathrm{L}$, and trace element concentration data indicated elevated concentrations of barium, lithium, strontium, and boron (tables 4 and 7). These results are similar to trace element results collected during phase 1 at wells completed in the lower aquifer (McMahon and others, 2013). Methane concentration was $100 \mathrm{mg} / \mathrm{L}$, and hydrocarbon gas molecular composition and $\delta^{13} \mathrm{C}$ of methane 


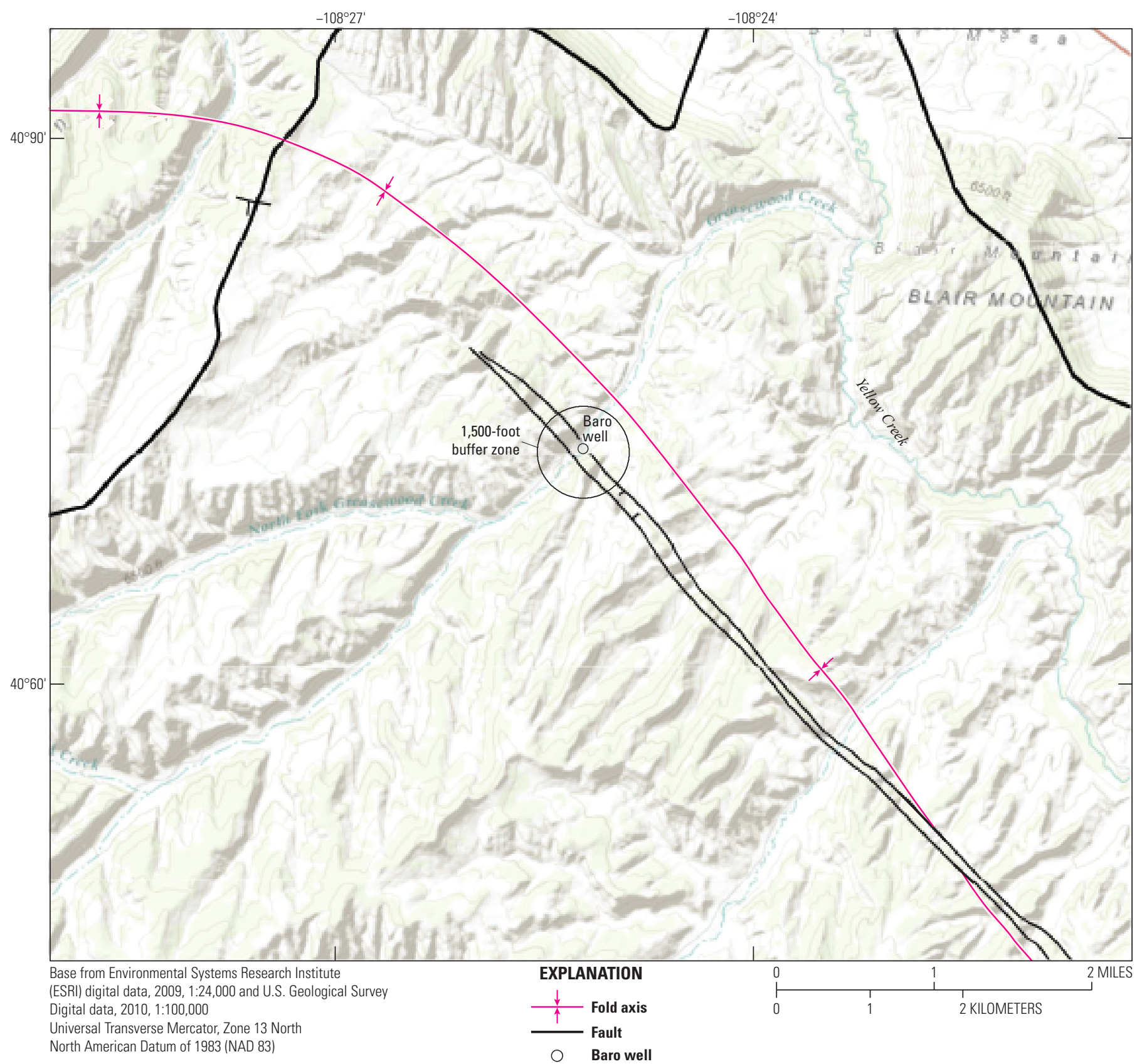

Figure 7. Location of geologic structures (faults and fold axes) near the Baro well (1,500-foot buffer zone around well), Piceance and Yellow Creek watersheds, Rio Blanco County, Colorado (geologic structure from Hail and Smith [1994, 1997]).

indicate the methane is biogenic in origin (table 6) using boundary conditions for biogenic and thermogenic methane from Bernard and others (1976) and Whiticar (1999). The $\delta^{13} \mathrm{C}$ of methane for the Baro well is isotopically lighter than that of wells with thermogenic methane like 13U (table 6). Toluene was detected at a concentration of $0.04 \mu \mathrm{g} / \mathrm{L}$, which again illustrates the widespread occurrence of VOCs in bedrock aquifers, even in areas with little or no energy development (table 5). The radiocarbon age for the Baro well was 48,129 plus or minus $( \pm$ ) 3,200 years (table 8 ). The tritium concentration for the Baro well was $0.1 \mathrm{TU}$, which is generally considered to represent old groundwater using criteria defined in McMahon and others (2013). Overall, water chemistry and groundwater age from the Baro well were similar to those of wells completed in the lower aquifer (McMahon and others, 2013). These chemical data indicate a mixing of groundwater between the upper and lower aquifers. The mixing may be due to the well's location near the regional discharge area and the nearby faults that could serve as pathways for the upward movement of groundwater from the lower aquifer to the upper aquifer. 
Table 7. Nutrient and trace element data for water collected from the Baro well, August 18, 2015, Piceance and Yellow Creek watersheds, Rio Blanco County, Colorado.

[mg/L, milligram per liter; $<$, less than; $\mu \mathrm{g} / \mathrm{L}$, microgram per liter $]$

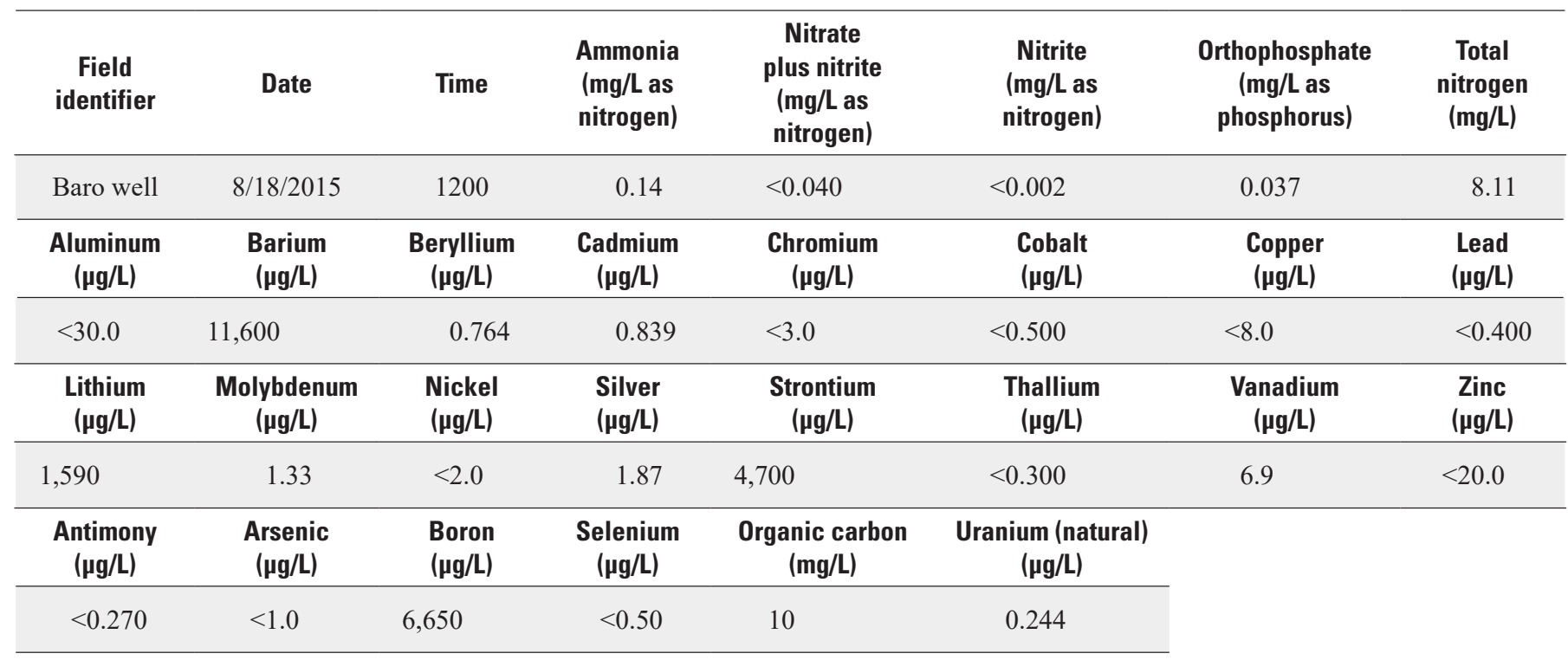

Table 8. Isotopic data and calculated radiocarbon age for water collected from the Baro well, August 18, 2015, Piceance and Yellow Creek watersheds, Rio Blanco County, Colorado.

[ $\Sigma$, sigma; $\delta$, delta; per mil, part per thousand]

\begin{tabular}{lc}
\hline \multicolumn{1}{c}{ Constituent, in units } & Value \\
\hline Carbon-14 of dissolved inorganic carbon, in percent modern & 0.25 \\
\hline Carbon-14 of dissolved inorganic carbon counting error, in percent modern & 0.1 \\
\hline Calculated radiocarbon age (normalized), in years & 48,129 \\
\hline Radiocarbon age error $1 \Sigma$ (normalized), in years & 3,200 \\
$\delta$ carbon-13/carbon-12, in per mil & 6.66 \\
$\delta$ hydrogen-2/hydrogen-1, in per mil & -139 \\
$\delta$ oxygen-18/oxygen-16, in per mil & -18.2 \\
Tritium, in tritium units & 0.1
\end{tabular}

\section{Water-Level Elevations}

Continuous water-level elevations were collected in wells $6 \mathrm{~A}$ and $6 \mathrm{~B}$ and wells $13 \mathrm{U}, 13 \mathrm{~A}$, and $13 \mathrm{~B}$ to provide information about temporal variability in daily mean waterlevel elevations and hydraulic gradients in the bedrock aquifers during water years 2013-16 (figs. 8 and 9). Wells 6A and $6 \mathrm{~B}$ were completed in the upper aquifer (Parachute Creek Member above the Mahogany zone) and the lower aquifer (Parachute Creek Member below the Mahogany zone), respectively. Water-level elevations at wells 6A and 6B generally decreased from water years 2013 to 2016 (fig. 8). During October 2012 through March 2015, the hydraulic gradient was consistently downward from the upper aquifer (6A) to the lower aquifer (6B). In early April 2015, the hydraulic gradient changed from downward to upward between the upper and lower aquifers (fig. 8). During early April 2015 to mid-June 2015, daily mean water-level elevations decreased by about $10 \mathrm{ft}$ in both wells (fig. 8), indicating some event caused this rapid decline in water-level elevations and the subsequent reversal in hydraulic gradient. Overall, daily mean water-level elevations declined by about 14 and $11 \mathrm{ft}$ in wells 6A and 6B, respectively, during water years 2013-16. McMahon and others (2013) estimated groundwater ages for wells $6 \mathrm{~A}$ and $6 \mathrm{~B}$ to be 1,200 and 9,600 years old, respectively. These groundwater ages indicate that groundwater was 


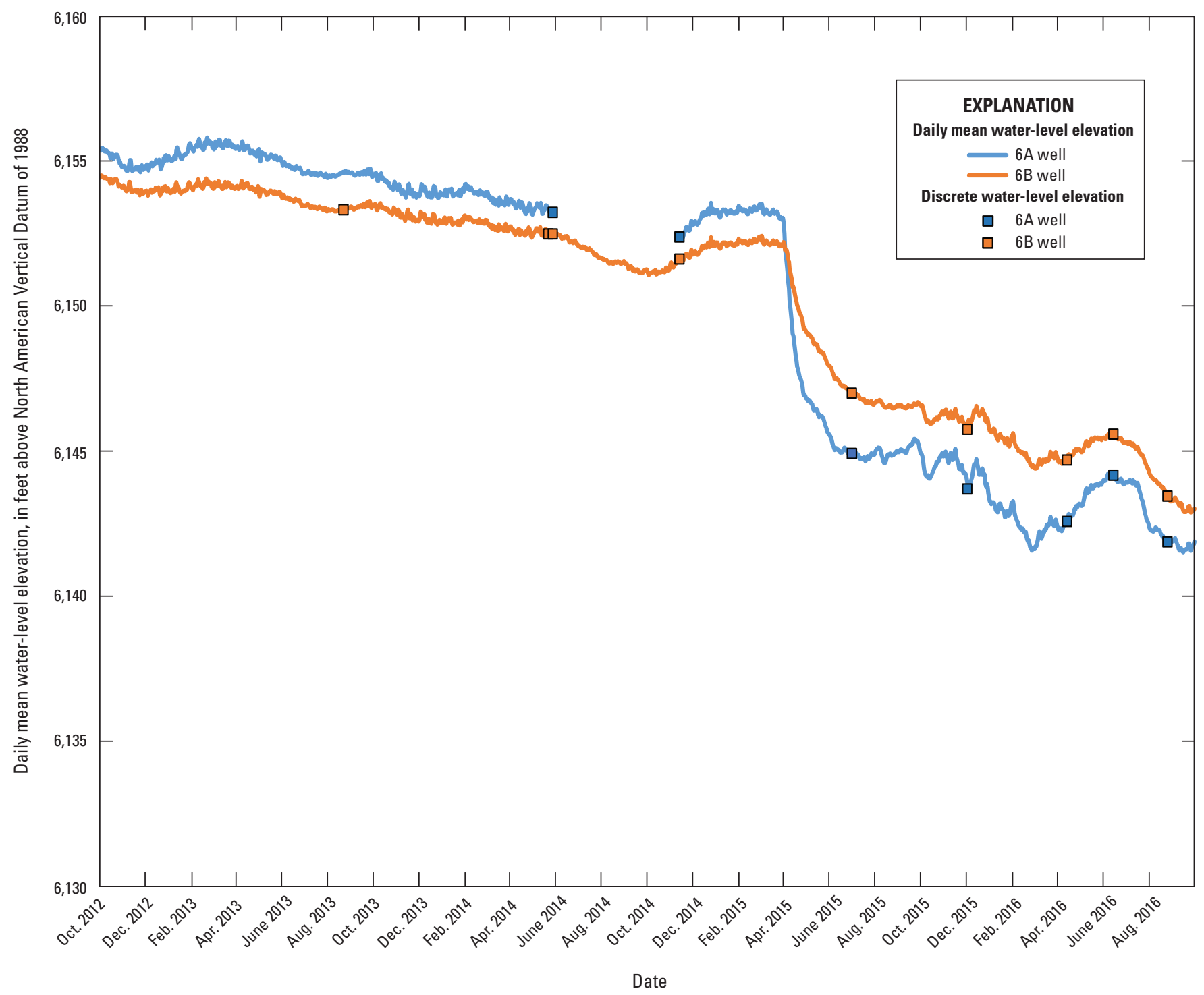

Figure 8. Daily mean water-level elevations in relation to time at wells 6A and 6B, water years 2013-16, Piceance and Yellow Creek watersheds, Rio Blanco County, Colorado.

recharged over thousands of years. With such long periods of time for aquifer recharge, declines in water-level elevation over short time steps (a few months) have important implications for sustainable management of this resource. Solution mining activities or drilling for oil and natural gas in the area could be related to changes in water-level elevations in these wells. Solution mining is about 2.5 miles to the south of the wells. Several well pads are near the wells where activities include drilling, hydraulic fracturing, and well stimulation. It was not clear if these land-use activities were related to the changes in observed water-level elevations; however, further investigation would be needed to evaluate the possible causation. Changes in major-ion chemistry, methane concentrations, water-level elevation, and hydraulic gradient provide multiple lines of evidence of change in the bedrock aquifer.

Wells $13 \mathrm{U}$ and 13A were completed in the upper aquifer, where $13 \mathrm{U}$ was completed in the Uinta Formation and 13A was completed in the Parachute Creek Member above the Mahogany zone. Well 13B was completed in the lower aquifer, which includes the Parachute Creek below the Mahogany zone. The gradient relative to the Parachute Creek above the Mahogany zone (13A) was upward into the Uinta (13U) and downward into the Parachute Creek below the Mahogany zone (13B) (fig. 9) and was consistent with the findings from phase 1 (McMahon and others, 2013). Daily mean water-level elevations at all three wells generally increased by about 2 to $2.5 \mathrm{ft}$ from water year 2013 to water year 2016 (fig. 9). During spring and summer of 2016, seasonal responses in water-level elevations were observed in the upper aquifer wells (13U and 13A) (fig. 9). Water-level elevations in the lower aquifer (13B) did not demonstrate the seasonal patterns observed in the upper aquifer, which indicates the lower aquifer is not hydraulically connected with the upper aquifer and that the Mahogany zone is a confining layer in this location. 


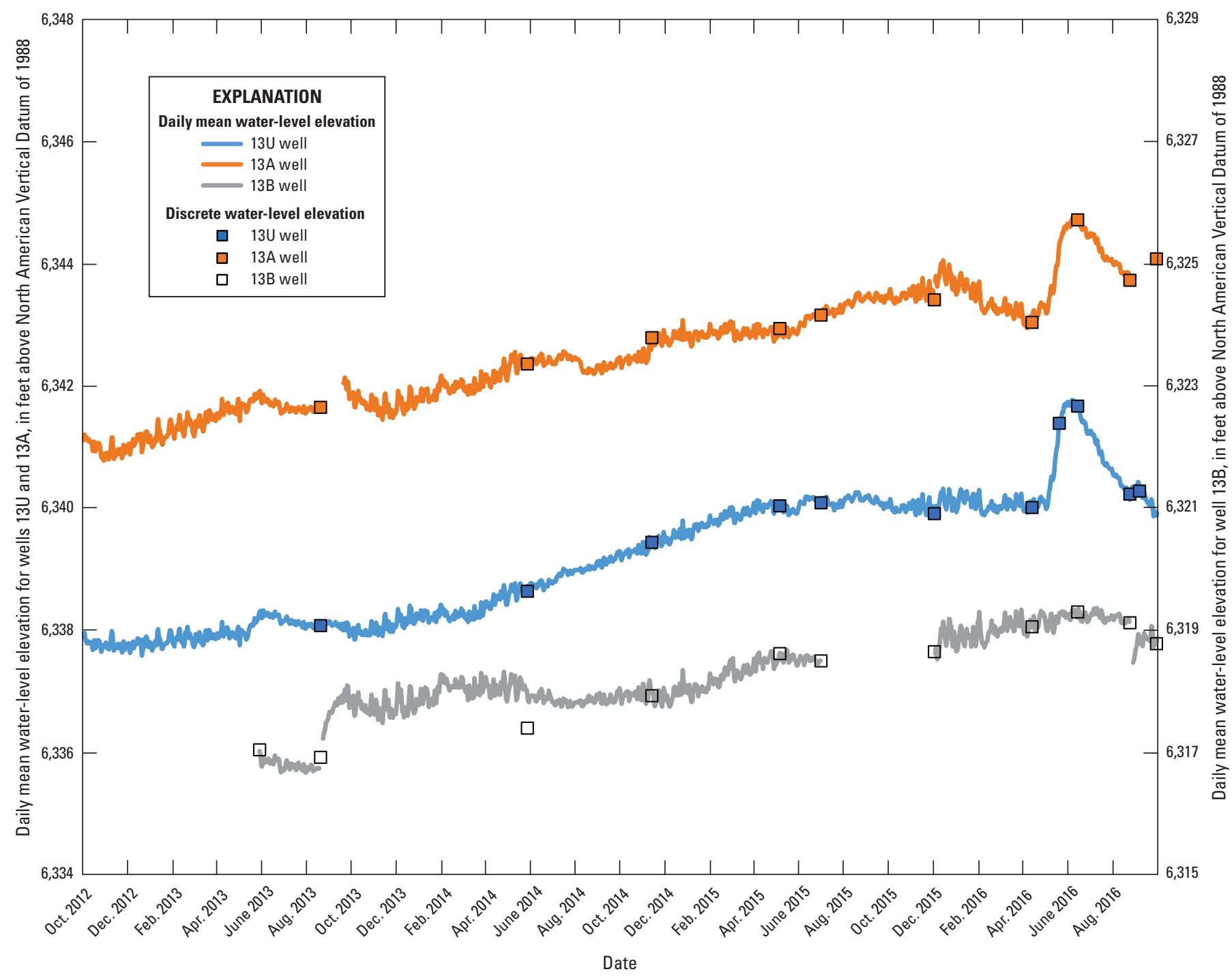

Figure 9. Daily mean water-level elevations in relation to time at wells 13U, 13A, and 13B, water years 2013-16, Piceance and Yellow Creek watersheds, Rio Blanco County, Colorado.

\section{Summary}

The Piceance and Yellow Creek watersheds in Rio Blanco County, Colorado, are known to contain important energy resources (oil shale and natural gas) and mineral resources (nahcolite). The primary sources of fresh groundwater in the Piceance and Yellow Creek watersheds are bedrock aquifers in the Uinta and Green River Formations. The aquifers are divided into an upper and lower aquifer separated by a regionally extensive semiconfining layer. These aquifers provide water to streams and springs in the watersheds and are an important resource to people living and working in the area. Development of these resources has the potential to affect the quality of shallow groundwater in the study area in several ways. Studies of groundwater chemistry and aquifer characterization have been done in relation to proposed oil-shale development. The lack of monitoring (as of 2010) of the shallow bedrock aquifers was identified by the Bureau of Land Management as a data gap that needed to be addressed. The Bureau of Land Management, White River Field Office, and the U.S. Geological Survey began groundwater monitoring in 2010 to characterize the groundwater quality of shallow bedrock aquifers in the Piceance and Yellow Creek watersheds. This first phase of monitoring (phase 1, 2010-12) established a monitoring-well network in the study area where wells were monitored for chemical constituents that could be related to the development of underlying natural-gas reservoirs. The second phase (phase 2, 2013-16) continues data collection from the monitoring-well network and builds on findings from phase 1. Phase 2 sampling focuses on monitoring groundwater for changes in constituent concentration using constituents selected to provide information on the overall groundwater quality and the occurrence of chemicals that could be related 
to the development of underlying oil and gas reservoirs. During phases 1 and 2, continuous water-level elevations were collected in five wells to provide information about temporal variability in water-level elevations and hydraulic gradients in the bedrock aquifers. Long-term monitoring of bedrock aquifers provides a tool to help differentiate natural variability in groundwater chemistry and water-level elevations from human-induced changes. The purpose of this report is to present groundwater chemistry and water-level elevations collected during 2013-16. Comparisons are made to data that were collected from the bedrock aquifers from 2010 to 2012 to identify the potential for changes in water quality and waterlevel elevations.

Reduction-oxidation (redox) data indicate that all samples collected during phase 2 were anoxic. Sulfate reduction and methanogenesis were important redox processes in anoxic groundwater in the study area based on dissolved sulfide and methane in water from several wells. The inverse relation observed between methane and sulfate is the result of sulfatereducing microbes outcompeting methanogens for electron donors needed to support their metabolism. Water types were generally mixed cation-bicarbonate-sulfate and sodium-bicarbonate water types. Time series plots of select major-ion data were evaluated from phase 1 and phase 2 to further understand potential changes in major-ion chemistry. Major-ion chemistry at well $6 \mathrm{~B}$ was variable in phase 1 and in phase 2 where alkalinity and sulfate were the most variable constituents. One possible explanation for the observed changes in major-ion chemistry may be that the sample depth used at well 6B may no longer represent the most appreciable flow in the borehole. On a larger scale, these changes in flow within the borehole may indicate changes in the regional flow system.

Methane concentrations in groundwater collected during phase 2 ranged from 0.048 to 160 milligrams per liter $(\mathrm{mg} / \mathrm{L})$. Methane concentrations in wells sampled during phase 1 and phase 2 were generally similar except for $6 \mathrm{~B}$ where methane concentrations were $57.4 \mathrm{mg} / \mathrm{L}$ in 2010 and $4.02 \mathrm{mg} / \mathrm{L}$ in 2013. During 2016, laboratory detection levels were lowered and analyses were expanded to increase the number of volatile organic compounds (VOCs) that were analyzed. These

changes resulted in an increased frequency of VOC detections. Detections of these compounds were at low concentrations but indicated the widespread and persistent occurrence of select VOCs in bedrock aquifers.

One recommendation from phase 1 was to evaluate sources and migration pathways of methane and VOCs in the study area by sampling a well where there was little energy development but where faults or fractures could provide a path for the migration of fluids from deep reservoirs to the shallow bedrock aquifers. The Baro well is in the Greasewood Creek drainage, which is tributary to Yellow Creek. The chemistry of water from the Baro well is similar to groundwater from the lower aquifer. Results from the Baro well indicate VOCs were in groundwater where there was little to no energy development. The mixing may be due to the well's location near the regional discharge area and the nearby faults that could serve as pathways for the upward movement of groundwater from the lower aquifer to the upper aquifer.

Continuous water-level elevations were collected in wells $6 \mathrm{~A}$ and $6 \mathrm{~B}$ and wells $13 \mathrm{U}, 13 \mathrm{~A}$, and 13B, providing information about temporal variability in water-level elevation and vertical hydraulic gradients in the bedrock aquifers. Wells 6A and 6B were completed in the upper aquifer (Parachute Creek Member above the Mahogany zone) and the lower aquifer (Parachute Creek below the Mahogany zone), respectively. From October 2012 through March 2015, the hydraulic gradient was consistently downward from the upper aquifer (6A) to the lower aquifer (6B). In early April 2015, the hydraulic gradient changed from downward to upward between the upper and lower aquifers. Overall, water-level elevations declined by about 14 and 11 feet in wells $6 \mathrm{~A}$ and $6 \mathrm{~B}$, respectively, during water years 2013-16. Estimated groundwater ages from phase 1 for $6 \mathrm{~A}$ and $6 \mathrm{~B}$ were 1,200 and 9,600 years old, respectively. These groundwater ages indicate that groundwater was recharged over thousands of years. With such long periods of time for aquifer recharge, declines in water-level elevation over short time steps (a few months) have important implications to sustainable management of this resource. Solution mining activities or drilling for oil and natural gas in the area could be related to the changes in observed water-level elevations in these wells; however, further investigation would be needed to evaluate causation. Changes in major-ion chemistry, methane concentrations, water-level elevation, and hydraulic gradient provide multiple lines of evidence of change in the bedrock aquifer.

Wells $13 \mathrm{U}$ and $13 \mathrm{~A}$ were completed in the upper aquifer, where $13 \mathrm{U}$ was completed in the Uinta Formation and 13A was completed in the Parachute Creek Member above the Mahogany zone. Well 13B was completed in the lower aquifer, which includes the Parachute Creek below the Mahogany zone. The gradient relative to the Parachute Creek above the Mahogany zone (13A) was upward into the Uinta (13U) and downward into the Parachute Creek below the Mahogany zone (13B) and was consistent with the findings from phase 1 . Water-level elevations at 13B did not show the seasonal patterns observed in $13 \mathrm{U}$ and $13 \mathrm{~A}$, which indicates the lower aquifer is not hydraulically connected with the upper aquifer indicating that the Mahogany zone is a confining layer in this location. 


\section{References Cited}

Bayer, R., Schlosser, P., Bonisch, G., Rupp, H., Zaucker, F., and Zimmek, G., 1989, Performance and blank components of a mass spectrometric system for routine measurement of helium isotopes and tritium by ${ }^{3} \mathrm{He}$ ingrowth method, in Sitzungsberichte der Heidelberger Akademie der Wissenschaften-Mathematisch-naturwissenschaftliche klasse: Heidelberg, Springer, p. 241-279.

Bernard, B.B., Brooks, J.M., and Sackett, W.M., 1976, Natural gas seepage in the Gulf of Mexico: Earth and Planetary Science Letters, v. 31, no. 1, p. 48-54. [Also available at https://doi.org/10.1016/0012-821X(76)90095-9.]

Brenton, R.W., and Arnett, T.L., 1993, Methods of analysis by the U.S. Geological Survey National Water Quality Laboratory-Determination of dissolved organic carbon by UVpromoted persulfate oxidation and infrared spectrometry: U.S. Geological Survey Open-File Report 92-480, 12 p.

Brownfield, M.E., Mercier, T.J., Johnson, R.C., and Self, J.G., 2010, Nahcolite resources in the Green River Formation, Piceance Basin, Colorado: U.S. Geological Survey Digital Data Series DDS-69-Y, chap. 2, 57 p., accessed February 14, 2012, at https://pubs.usgs.gov/dds/dds-069/dds-069-y/.

Busenberg, E., Weeks, E.P., Plummer, L.N., and Bartholomay, R.C., 1993, Age dating ground water by use of chlorofluorocarbons $\left(\mathrm{CCl}_{3} \mathrm{~F}\right.$ and $\left.\mathrm{CCl}_{2} \mathrm{~F}_{2}\right)$, and distribution of chlorofluorocarbons in the unsaturated zone, Snake River Plain aquifer, Idaho National Engineering Laboratory, Idaho: U.S. Geological Survey Water-Resources Investigations Report 93-4054, 47 p.

Cashion, W.B., and Donnell, J.R., 1974, Revision of nomenclature of the upper part of the Green River Formation, Piceance Creek Basin, Colorado, and eastern Uinta Basin, Utah: U.S. Geological Survey Bulletin 1394-G, 20 p.

Childress, C.J.O., Foreman, W.T., Connor, B.F., and Maloney, T.J., 1999, New reporting procedures based on longterm method detection levels and some considerations for interpretations of water-quality data provided by the U.S. Geological Survey National Water Quality Laboratory: U.S. Geological Survey Open-File Report 99-193, 19 p. [Also available at https://doi.org/10.3133/ofr99193.]

Coffin, D.L., Welder, F.A., and Glanzman, R.K., 1971, Geohydrology of the Piceance Creek structural basin between the White and Colorado Rivers, northwestern Colorado: U.S. Geological Survey Hydrologic Atlas 370, 2 sheets.

Colorado Oil and Gas Conservation Commission, 2017, Colorado Oil and Gas information system: Colorado Oil and Gas Conservation Commission web page, accessed September 26, 2017, at http://cogcc.state.co.us/.
Cunningham, W.L., and Schalk, C.W., comps., 2011, Groundwater technical procedures of the U.S. Geological Survey: U.S. Geological Survey Techniques and Methods, book 1, chap. A1, 151 p., accessed January 1, 2013, at https://pubs. usgs.gov/tm/1a1/.

Day, M., Hansen, E., Gulliver, T., and Mckinzie, B., 2010, Northwest Piceance Creek Basin hydrogeology, in Proceedings of the 30th Oil Shale Symposium, Golden, Colo., October 18-20, 2010: Golden, Colo., 2010, Shell Exploration and Production Co., 29 p. [Also available at http:// www.costar-mines.org/oss/30/paper/Paper_14-02-Hansen Erik.pdf.]

Donnell, J.R., 2009, Intertonguing of the lower part of the Uinta Formation with the upper part of the Green River Formation in the Piceance Creek Basin during the late stages of Lake Uinta: U.S. Geological Survey Scientific Investigations Report 2008-5237, 25 p.

Dubiel, R.F., 2003, Geology, depositional models, and oil and gas assessment of the Green River total petroleum system, Uinta-Piceance Province, eastern Utah and western Colorado, in U.S. Geological Survey Uinta-Piceance Assessment Team, comps., Petroleum systems and geologic assessment of oil and gas in the Uinta-Piceance Province, Utah and Colorado: U.S. Geological Survey Digital Data Series DDS-069-B, chap. 5, 45 p., accessed February 14, 2012, at https://pubs.usgs.gov/dds/dds-069/dds-069-b/.

Eltschlager, K.K., Hawkins, J.W., Ehler, W.C., and Baldassare, F., 2001, Technical measures for the investigation and mitigation of fugitive methane hazards in areas of coal mining: Office of Surface Mining Reclamation and Enforcement, 125 p., accessed September 25, 2017, at https://www.osmre. gov/resources/library/ghm/methane.pdf.

Finley, B., 2013, Parachute Creek spill continues uncontained; cause, source unknown: Denver Post, March 18, 2013, accessed May 2, 2018, at https://www.denverpost. com/2013/03/18/parachute-creek-spill-continues-uncontained-cause-source-unknown/.

Fishman, M.J., 1993, Methods of analysis by the U.S. Geological Survey National Water Quality Laboratory; determination of inorganic and organic constituents in water and fluvial sediments: U.S. Geological Survey Open-File Report 93-125, $217 \mathrm{p}$.

Fishman, M.J., and Friedman, L.C., 1989, Methods for determination of inorganic substances in water and fluvial sediments: U.S. Geological Survey Techniques of WaterResources Investigations, book 5, chap. A1, 545 p. 
Freeman, L.A., Carpenter, M.C., Rosenberry, D.O., Rousseau, J.P., Unger, R., and McLean, J.C. 2004, Use of submersible pressure transducers in water-resources investigations: U.S. Geological Survey Techniques of Water-Resources Investigations, book 8, chap. A3, 52 p., accessed January 1, 2013, at https://doi.org/10.3133/twri08A3

Garbarino, J.R., Kanagy, L.K., and Cree, M.E., 2006, Determination of elements in natural-water, biota, sediment, and soil samples using collision/reaction cell inductively coupled plasma-mass spectrometry: U.S. Geological Survey Techniques and Methods, book 5, chap. B1, 88 p.

Hach, 2018, Sulfide, HR, Methylene Blue Method 1: Hach web page, accessed March 15, 2018, at https://www.hach. com/sulfide-reagent-set-methylene-blue/product-downloads $? \mathrm{id}=7640198750 \&$ callback $=\mathrm{qs}$.

Hail, W.J., Jr., 1990, Geology of the lower Yellow Creek area, northwestern Colorado: U.S. Geological Survey Bulletin 1787-O, 45 p.

Hail, W.J., and Smith, M.C., 1994, Geologic map of the northern part of the Piceance Creek basin, northwestern Colorado: U.S. Geological Survey Miscellaneous Investigations Series Map I-2400, scale 1:100,000.

Hail, W.J., and Smith, M.C., 1997, Geologic map of the southern part of the Piceance Creek basin, northwestern Colorado: U.S. Geological Survey Miscellaneous Investigations Series Map I-2529, scale 1:100,000.

Hem, J.D., 1985, Study and interpretation of chemical characteristics of natural water, $3 d$ ed.: U.S. Geological Survey Water-Supply Paper 2254, 264 p.

Hess, A.E., 1986, Identifying hydraulically conductive fractures with a slow-velocity borehole flowmeter: Canadian Geotechnical Journal, v. 23, no. 1, p. 69-78. [Also available at https://doi.org/10.1139/t86-008.]

Isotech Laboratories, Inc., 2018a, Sampling products, other, dissolved gas container: Isotech Laboratories, Inc., web page, accessed May 2, 2018, at http://www.isotechlabs.com/ products/isoflask/.

Isotech Laboratories, Inc., 2018b, Analytical services, view by isotopes, carbon: Isotech Laboratories, Inc., web page, accessed May 2, 2018, at http://www.isotechlabs.com/analytical/isotope/carbon.html.

Isotech Laboratories, Inc., 2018c, Analytical services, view by sample type, gas, compositional: Isotech Laboratories, Inc., web page, accessed May 2, 2018, at http://www.isotechlabs. com/analytical/sampletype/gas/compositional/.

Johnson, R.C., 1981, Stratigraphic evidence for a deep Eocene Lake Uinta, Piceance Creek Basin, Colorado: Geology, v. 9, no. 2, p. 55-62. [Also available at https://doi. org/10.1130/0091-7613(1981)9<55:SEFADE >2.0.CO;2.]
Johnson, R.C., and Rice, D.D., 1990, Occurrence and geochemistry of natural gases, Piceance Basin, northwest Colorado: The American Association of Petroleum Geologists Bulletin, v. 74, no. 6, p. 805-829. [Also available at https://doi.org/10.1306/0C9B2399-1710-11D78645000102C1865D.]

Johnson, R.C., Mercier, T.J., Brownfield, M.E., Pantea, M.P., and Self, J.G., 2010, An assessment of in-place oil shale resources in the Green River Formation, Piceance Basin, Colorado: U.S. Geological Survey Digital Data Series DDS-069-Y, chap. 1, 187 p, accessed January 1, 2013, at https://pubs.usgs.gov/dds/dds-069/dds-069-dd/ REPORTS/69_DD_CH_1.pdf.

Kimball, B.A., 1984, Groundwater age determinations, Piceance Creek basin, Colorado, in Proceedings of the First Canadian/American Conference on Hydrogeology, Practical Applications of Groundwater Geochemistry, Banff, Alberta, Canada, June 22-26, 1984: Worthington, Ohio, National Water Well Association, p. 267-283.

King, G.E., and King, D.E., 2013, Environmental risk arising from well construction failure-Difference between barrier and well failure, and estimates of failure frequency across common well types, locations, and well age: SPE Annual Technical Conference and Exhibition, New Orleans, La., September 30-October 2, 2013, SPE-166142-MS. [Also available at https://doi.org/10.2118/166142-MS.]

Lovley, D.R., and Klug, M.J., 1986, Model for the distribution of sulfate reduction and methanogenesis in freshwater sediments: Geochimica et Cosmochimica Acta, v. 50, no. 1, p. 11-18. [Also available at https://doi.org/10.1016/00167037(86)90043-8.]

McMahon, P.B., and Chapelle, F.H., 2008, Redox processes and water quality of selected principal aquifer systems: Ground Water, v. 46, no. 2, p. 259-271. [Also available at https://doi.org/10.1111/j.1745-6584.2007.00385.x.]

McMahon, P.B., Thomas, J.C., and Hunt, A.G., 2013, Chemistry and age of groundwater in bedrock aquifers of the Piceance and Yellow Creek watersheds, Rio Blanco County, Colorado, 2010-12: U.S. Geological Survey Scientific Investigations Report 2013-5132, 89 p. [Also available at https://pubs.usgs.gov/sir/2013/5132/.]

Molz, F.J., Boman, G.K., Young, S.C., and Waldrop, W.R., 1994, Borehole flowmeters-Field application and data analysis: Journal of Hydrology, v. 163, no. 3-4, p. 347-371. [Also available at https://doi.org/10.1016/00221694(94)90148-1.]

Natural Soda, 2017, Our unique process: Natural Soda web page, accessed October 6, 2017, at http://www.naturalsoda. com/OurUniqueProcess.aspx. 
Ortiz, R.F., 2002, Baseline characterization of water quality and mass loading in Piceance Creek, Rio Blanco County, Colorado, December 2000: U.S. Geological Survey WaterResources Investigations Report 2002-4134, 41 p.

Révész, K., and Coplen, T.B., 2008a, Determination of the $\delta\left({ }^{2} \mathrm{H} /{ }^{1} \mathrm{H}\right)$ of water-RSIL lab code 1574 : U.S. Geological Survey Techniques and Methods, book 10, chap. C1, 27 p. [Also available at https://pubs.er.usgs.gov/publication/ tm10C1.]

Révész, K., and Coplen, T.B., 2008b, Determination of the $\delta\left({ }^{18} \mathrm{O} /{ }^{16} \mathrm{O}\right)$ of water-RSIL lab code 489: U.S. Geological Survey Techniques and Methods, book 10, chap. C2, 28 p. [Also available at https://pubs.usgs.gov/tm/2007/tm10c2.]

Robson, S.G., and Saulnier, G.J., Jr., 1981, Hydrogeochemistry and simulated solute transport, Piceance Basin, Northwestern Colorado: U.S. Geological Survey Professional Paper 1196, 65 p.

Rose, D.L., Sandstrom, M.W., and Murtagh, L.K., 2016, Determination of heat purgeable and ambient purgeable volatile organic compounds in water by gas chromatography/mass spectrometry: U.S. Geological Survey Techniques and Methods, book 5, chap. B12, 62 p.

Rounds, S.A., 2006, Alkalinity and acid neutralizing capacity (ver. 3.0): U.S. Geological Survey Techniques of WaterResources Investigations, book 9, chap. A6., sec. 6.6, July 2006, accessed October 17, 2018, at https://pubs.water. usgs.gov/twri9A6/.

Slawson, G.C., Jr., Kelly, K.E., and Everett, L.G., 1982, Evaluation of ground-water pumping and bailing methods application in the oil shale industry: Ground Water Monitoring and Remediation, v. 2, no. 3, p. 27-32. [Also available at https://doi.org/10.1111/j.1745-6592.1982.tb00836.x.]

Stuiver, M., 1980, Workshop on ${ }^{14} \mathrm{C}$ data reporting: Radiocarbon, v. 22, no. 3, p. 964-966. [Also available at https://doi. org/10.1017/S0033822200010389.]

Stuiver, M., and Polach, H.A., 1977, Discussion-Reporting of ${ }^{14} \mathrm{C}$ data: Radiocarbon, v. 19, no. 3, p. 355-363. [Also available at https://doi.org/10.1017/S0033822200003672.]

U.S. Geological Survey [USGS], 2006, Collection of water samples (ver. 2.0): U.S. Geological Survey Techniques of Water-Resources Investigations, book 9, chap. A4, accessed June 31, 2013, at https://pubs.water.usgs.gov/twri9A4/.

U.S. Geological Survey [USGS], 2017a, Dissolved gas $\mathrm{N}_{2} / \mathrm{Ar}$ sample collection procedure: U.S. Geological Survey web page, accessed October 20, 2017, at https://water.usgs.gov/ lab/dissolved-gas/sampling/.
U.S. Geological Survey [USGS], 2017b, Instructions for collecting samples: U.S. Geological Survey web page, accessed October 20, 2017, at https://isotopes.usgs.gov/lab/ instructions.html.

U.S. Geological Survey [USGS], 2018, USGS water data for the Nation: U.S. Geological Survey National Water Information System database: accessed January 1, 2015, at https://doi.org/10.5066/F7P55KJN.

U.S. Government Accountability Office, 2018, Energy-water nexus - A better and coordinated understanding of water resources could help mitigate the impacts of potential oil shale development: U.S. Government Accountability Office, Report to Congressional Requestors, GAO-11-35, accessed April 27, 2018, at https://www.gao.gov/products/ GAO-11-35.

Warner, N.R., Jackson, R.B., Darrah, T.H., Osborn, S.G., Down, A., Zhao, K., White, A., and Vengosh, A., 2012, Geochemical evidence for possible natural migration of Marcellus Formation brine to shallow aquifers in Pennsylvania: Proceedings of the National Academy of Sciences of the United States of America, v. 109, no. 30, p. 11961-11966. [Also available at https://doi.org/10.1073/ pnas.1121181109.]

Watson, T.L., and Bachu, S., 2009, Evaluation of the potential for gas and CO2 leakage along wellbores: SPE Drilling and Completion, v. 24, no. 1, p. 115-126. [Also available at https://doi.org/10.2118/106817-PA.]

Weeks, J.B., Leavesley, G.H., Welder, F.A., and Saulnier, G.J., Jr., 1974, Simulated effects of oil-shale development on the hydrology of Piceance Basin, Colorado: U.S. Geological Survey Professional Paper 908, 84 p.

Welder, F.A., and Saulnier, G.J., Jr., 1978, Geohydrologic data from twenty-four test holes drilled in the Piceance Basin, Rio Blanco County, Colorado, 1975-76: U.S. Geological Survey Open-File Report 78-734, 132 p.

Whiticar, M.J., 1999, Carbon and hydrogen isotope systematics of bacterial formation and oxidation of methane: Chemical Geology, v. 161, no. 1-3, p. 291-314. [Also available at https://doi.org/10.1016/S0009-2541(99)00092-3.]

Wilde, F.D., Radtke, D.B., Gibs, J., and Iwatsubo, R.T., eds., 2004 with updates through 2009, Processing of water samples (ver. 2.2): U.S. Geological Survey Techniques of Water-Resources Investigations, book 9, chap. A5, April 2004, accessed June 31, 2013, at https://pubs.water. usgs.gov/twri9A5/. 
Williams, D., 2011, Fines for Garden Gulch drilling spills finally to be imposed after more than three years: The Colorado Independent, June 21, 2011, accessed May 2, 2018, at http://www.coloradoindependent.com/91659/finesfor-garden-gulch-drilling-spills-finally-to-be-imposed-aftermore-than-three-years.

Woods Hole Oceanographic Institution, 2018, National Ocean Sciences Accelerator Mass Spectrometry: Woods Hole Oceanographic Institution web page, accessed May 1, 2018, at http://www.whoi.edu/nosams/home. 
For additional information, contact:

Director, Colorado Water Science Center

U.S. Geological Survey

Box 25046, Mail Stop 415

Denver, CO 80225

(303) 236-6901

Or visit our website at: https://co.water.usgs.gov/

Publishing support provided by the Denver, Rolla, and West Trenton Publishing Service Centers 


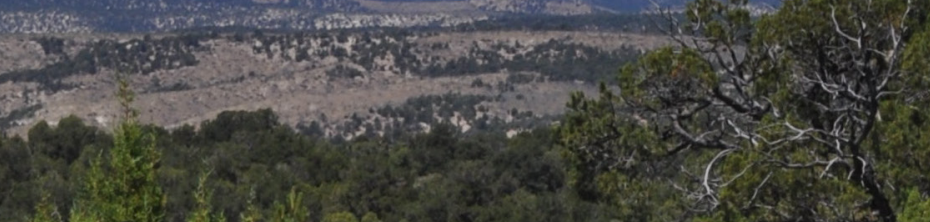

2.5. 준

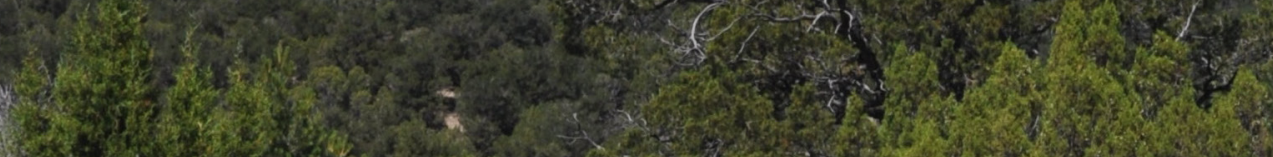

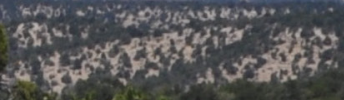

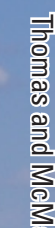

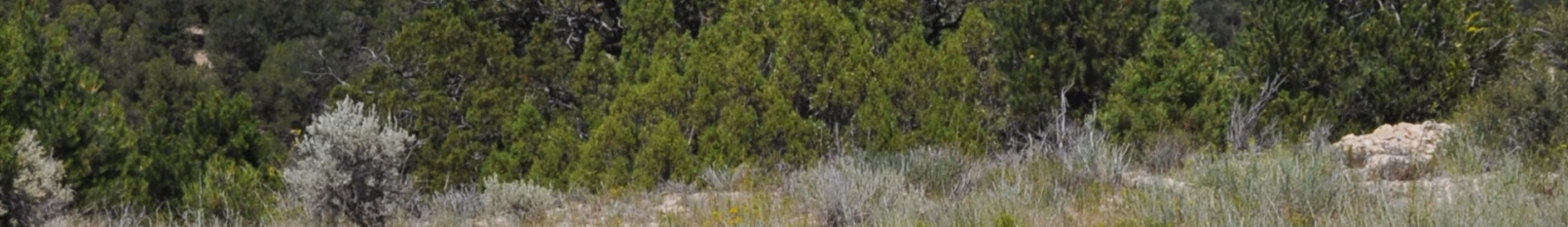

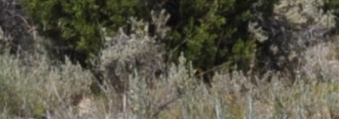

